\title{
VOC emissions, evolutions and contributions to SOA formation at a receptor site in eastern China
}

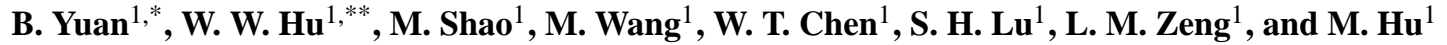 \\ ${ }^{1}$ State Joint Key Laboratory of Environmental Simulation and Pollution Control, College of Environmental Sciences and \\ Engineering, Peking University, Beijing, 100871, China \\ *now at: Earth System Research Laboratory, Chemical Sciences Division, NOAA, 325 Broadway, Boulder, Colorado 80305, \\ USA \\ *** now at: Cooperative Institute for Research in Environmental Sciences, University of Colorado, Boulder, CO 80309, USA
}

Correspondence to: M. Shao (mshao@pku.edu.cn)

Received: 6 December 2012 - Published in Atmos. Chem. Phys. Discuss.: 13 March 2013

Revised: 10 June 2013 - Accepted: 29 July 2013 - Published: 4 September 2013

\begin{abstract}
Volatile organic compounds (VOCs) were measured by two online instruments (GC-FID/MS and PTR-MS) at a receptor site on Changdao Island $\left(37.99^{\circ} \mathrm{N}, 120.70^{\circ} \mathrm{E}\right)$ in eastern China. Reaction with $\mathrm{OH}$ radical dominated chemical losses of most VOC species during the Changdao campaign. A photochemical-age-based parameterization method is used to calculate VOC emission ratios and to quantify the evolution of ambient VOCs. The calculated emission ratios of most hydrocarbons agree well with those obtained from emission inventory data, but determined emission ratios of oxygenated VOCs (OVOCs) are significantly higher than those from emission inventory data. The photochemical-agebased parameterization method is also used to investigate primary emissions and secondary formation of organic aerosol. The primary emission ratio of organic aerosol $(\mathrm{OA})$ to $\mathrm{CO}$ is determined to be $14.9 \mu \mathrm{g} \mathrm{m}^{-3} \mathrm{ppm}^{-1}$, and secondary organic aeorosols (SOA) are produced at an enhancement ratio of $18.8 \mathrm{\mu g} \mathrm{m}^{-3} \mathrm{ppm}^{-1}$ to $\mathrm{CO}$ after $50 \mathrm{~h}$ of photochemical processing in the atmosphere. SOA formation is significantly higher than the level determined from VOC oxidation under both high- $\mathrm{NO}_{\mathrm{x}}\left(2.0 \mu \mathrm{g} \mathrm{m}^{-3} \mathrm{ppm}^{-1} \mathrm{CO}\right)$ and low- $\mathrm{NO}_{\mathrm{x}}$ conditions $\left(6.5 \mu \mathrm{g} \mathrm{m}^{-3} \mathrm{ppm}^{-1} \mathrm{CO}\right)$. Polycyclic aromatic hydrocarbons (PAHs) and higher alkanes (> C10) account for as high as $17.4 \%$ of SOA formation, which suggests semi-volatile organic compounds (SVOCs) may be a large contributor to SOA formation during the Changdao campaign. The SOA formation potential of primary VOC emissions determined from field campaigns in Beijing and Pearl River Delta (PRD) is lower than the measured SOA levels reported in the two re-
\end{abstract}

gions, indicating SOA formation is also beyond explainable by VOC oxidation in the two city clusters.

\section{Introduction}

Volatile organic compounds (VOCs) are key constituents in the atmosphere, as precursors of tropospheric ozone and secondary organic aerosols (SOA). VOCs are oxidized by $\mathrm{OH}$ radical, ozone and $\mathrm{NO}_{3}$ radical as soon as they are emitted from primary sources into the atmosphere. VOC lifetimes in the atmosphere are controlled by the rate constants of VOCs with these oxidants, which span across several orders of magnitude (Parrish et al., 2007). In most environments, reactions with $\mathrm{OH}$ radical are the dominant sink for various VOCs (Warneke et al., 2004). Oxygenated VOCs (OVOCs) can also be formed from the oxidations of other VOC species (de Gouw et al., 2005). Thus, VOC evolution provides a perspective to understand the chemical mechanisms in the atmosphere (Apel et al., 2010).

Although SOA formation in the atmosphere has been of concern since the 1980s, recent evidence has shown that ambient SOA concentrations are significantly larger than the predicted levels (de Gouw et al., 2005; Heald et al., 2005; Matsui et al., 2009; Volkamer et al., 2006). The reasons for the discrepancies are found in the latest laboratory and field measurements: (1) SOA yields of many VOC species have strong dependence on $\mathrm{NO}_{\mathrm{x}}$ level $(\mathrm{Ng}$ et al., 2007); (2) small VOC species are also identified as important SOA 
precursors (Volkamer et al., 2007, 2009); (3) SOA formation from biogenic-originated VOCs could be enhanced by anthropogenic emissions (Goldstein et al., 2009); (4) semivolatile organic compounds are significant contributors to SOA formation (Robinson et al., 2007). Using these new findings, the gaps between measured and modeled SOA concentrations are significantly reduced in some environments (Bahreini et al., 2009; Dzepina et al., 2009; Capes et al., 2009), but the physical/chemical properties of SOA (e.g. the $\mathrm{O}: \mathrm{C}$ ratio) are found to be difficult to reproduce.

The importance of SOA in organic aerosol (OA) in China was initially explored by OC/EC ratios (organic carbon to element carbon) in various environments (Zhang et al., 2008a) and chemical mass balance (CMB) models by using organic molecular tracers (Zheng et al., 2005). Recently, the results from an aerosol mass spectrometer (AMS) showed that SOA accounted for about half of organic aerosols at urban sites (Huang et al., 2010) and even higher at rural sites (Huang et al., 2011). Recently, regional air quality models were used to study SOA formation in China (Fu et al., 2012; Jiang et al., 2012; Han et al., 2008). The modeled concentrations and budgets of SOA in these studies have strong dependence on the estimates in VOC emission inventories of China, associated with large uncertainties (Zhang et al., 2009). The uncertainties of emission inventory data prevent, at least partially, an accurate judgment on the discrepancies between modeling results and ambient measurements (Jiang et al., 2012).

Central eastern China (CEC) has been identified as a hotspot of air pollution, with high density of population in China (van Donkelaar et al., 2010). Ground-based and satellite measurements show that the levels of air pollutants, such as $\mathrm{NO}_{2}$ (van der A et al., 2008) and formaldehyde (De Smedt et al., 2010), keep on increasing. The impact of central eastern China outflow to other neighboring countries (e.g. Korea and Japan) and the west Pacific Ocean has been of increasing concern (Kondo et al., 2011).

An intensive filed campaign (Campaign of Air Pollution at Typical Coastal Areas in Eastern China, CAPTAIN), aiming at transport and evolution of trace gases and aerosol in the outflow of central eastern China, was conducted during the period 20 March-25 April 2011. VOCs and organic aerosol were simultaneously measured at a rural site using state-ofthe-art instruments. In this study, VOC evolution and SOA formation will be investigated by a parameterization method based on photochemical age. The determined VOC emission ratios in the campaign are compared with those obtained in other regions and in emission inventory data. SOA formation from VOC oxidation are calculated and compared with the measured SOA. The reasons for discrepancies between measured and calculated SOA will be further explored.

\section{Measurements}

A rural receptor site on Changdao Island (Changdao, Fig. 1) was selected for this campaign. Changdao Island lies between Liaoning Peninsula and Jiaodong Peninsula, $20 \mathrm{~km}$ off the coast of the mainland. The sampling site $\left(37.99^{\circ} \mathrm{N}\right.$, $120.70^{\circ} \mathrm{E}$ ) was on the top of a hill with a height of about $30 \mathrm{~m}$ above ground. In this study, VOCs were measured by two online instruments, namely gas chromatography with a mass spectrometer detector and a flame ionization detector (GC-MS/FID) and a proton transfer reaction mass spectrometer (PTR-MS).

The custom-built online GC-MS/FID was a two-channel system and was capable of measuring $\mathrm{C} 2-\mathrm{C} 10$ hydrocarbons and selected C2-C5 carbonyls. This system was described by our previous paper (Yuan et al., 2012) and only small modifications of the system are presented here. Samples are collected into GC-MS/FID for 5 min every $1 \mathrm{~h}$ at a flow of 60 $\mathrm{mL} \min ^{-1}$. Most of the $\mathrm{C} 2-\mathrm{C} 5$ hydrocarbons were measured by the FID channel and other species were recorded from the MS channel. In the first period (20 March-1 April) of the campaign, internal standards were injected into the system after collecting the ambient samples to record the variability of the instrument stability. However, the injection of the internal standard brought some interference from the sampling lines or the internal standard canister. The internal standard was abandoned in the second period of the campaign (2-25 April) and only data in the second period is used in the following analysis. The signal variations of various VOC species due to system instability were corrected by the signal of 1,1,2-trichloro-1,2,2-trifluoroethane (CFC-113). As a result of low emissions, concentrations of CFC-113 are quite stable in a period of 1 month in the atmosphere. Sensitivities of various VOC species were calibrated by two gas standards with 55 and 63 compounds, respectively (Spectra Gases Inc., USA, and Apel-Riemer Environmental Inc., USA). The precision of the system for hydrocarbons and OVOCs was better than $5 \%$ and $10 \%$, respectively. The measured uncertainties of different species were calculated as being lower than $15 \%$. Detection limits for various compounds were in the range of 0.002-0.070 ppb (Yuan et al., 2012).

VOCs were also measured by a commercial PTR-MS (Ionicon Analytik, Innsbruck, Austria). The setup of the instrument was identical to the Beijing measurements in our previous paper (Yuan et al., 2012). Six additional masses were recorded $(m / z 54, m / z 83, m / z 89, m / z 95, m / z 129$ and $m / z$ 135) during the Changdao campaign, resulting in a total of 28 masses during the campaign. Background signals were measured for 15 min every $2.5 \mathrm{~h}$ by passing ambient air through a platinum catalytic converter at $350{ }^{\circ} \mathrm{C}$ (Shimadzu Inc., Japan). Aromatics, oxygenates, isoprene and acetonitrile were calibrated by a cylinder gas standard from ApelRiemer Environmental Inc., USA. Formic acid $(m / z 47)$, acetic acid $(\mathrm{m} / \mathrm{z} 61)$ and monoterpenes $(\mathrm{m} / \mathrm{z} 81$ and $\mathrm{m} / \mathrm{z}$ 137) were calibrated by permeation tubes (Kin-Tek, USA). 

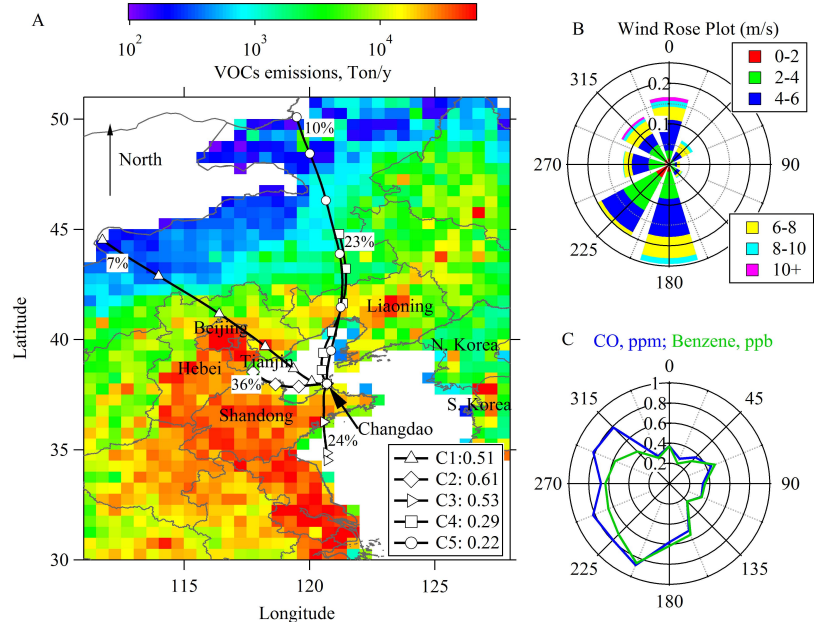

Fig. 1. (A) Location of the Changdao site. The areas are color-coded using VOC emissions strength (Zhang et al., 2009).The black lines are the $48 \mathrm{~h}$ back trajectory cluster of the Changdao site during the campaign. The numbers in the legend show the average $\mathrm{CO}$ concentrations (ppm) in each cluster. (B) Wind rose plot during the campaign. (C) Distributions of CO and benzene average concentrations with wind direction during the Changdao campaign. Data with wind speed lower than $0.5 \mathrm{~m} \mathrm{~s}^{-1}$ are filtered out.

The interferences of ethyl acetate to acetic acid at $m / z 61$ were corrected by $m / z 89$ signals (Fig. S1). $m / z 129$ was attributed to naphthalene (Bon et al., 2011) and its sensitivity was adapted from the calibration factor of $\mathrm{C} 10$ aromatics in the channel of $m / z$ 135. Measurement uncertainty of naphthalene is somewhat larger than other species and it is estimated to be within $50 \%$.

An Aerodyne high-resolution time-of-flight aerosol mass spectrometer (HR-TOF-AMS) was also deployed at the site to continuously measure the chemical compositions of submicron aerosols $\left(\mathrm{PM}_{1}\right)$, including sulfate, nitrate, chlorine, ammonium and OA. Chemical compositions of $\mathrm{PM}_{1}$ were reported at a time resolution of $4 \mathrm{~min}$. A detailed description of the AMS system setup and data processing are shown in a separate paper (Hu et al., 2013).

Photolysis frequencies were determined from actinic flux spectra recorded by a multi-channel spectrometer (MCS) with photodiode array (PDA) (CarlZeiss MicroImaging $\mathrm{GmbH})$. $\mathrm{CO}$ was measured by a commercial non-dispersive infrared sensor (NDIR) based on the gas filter correlation method (Thermo Environmental Instruments, TEI Inc., Model $48 \mathrm{C}$ ). $\mathrm{NO}$ and $\mathrm{NO}_{2}$ were measured by a chemiluminescence trace level analyzer (Ecotech Model 9841). Ozone was measured by an UV adsorption ozone analyzer (TEI, Model 49C). Temperature, relative humidity, wind speed and wind direction were measured by an automatic meteorological station (500 $\mathrm{m}$ away from the Changdao site) operated by Bureau of Meteorology of Changdao County.
This study will mainly focus on evolutions of urban emissions; thus data filtering is needed for the following analysis. During the campaign, two biomass burning plumes were identified from acetonitrile and $\mathrm{CO}$ concentrations on 31 March and 6 April, respectively. The Changdao site was also occasionally influenced by coal burning emissions from nearby small factories. Coal burning plumes were identified from the spikes of naphthalene, benzene and $\mathrm{CO}$ concentrations. Ocean emissions to VOCs are found to be minor in this study, as indicated by the low VOC concentrations when air masses passed over the Bohai Sea from the north (Sect. 3.1). Measurement data during the periods with influences from biomass burning and coal burning were filtered out from the analysis in this study. The filtered data from various instruments are averaged according to sampling time of GC-MS/FID for the further analysis.

\section{Results}

\subsection{VOC concentrations and influences from regional transport}

Measured hydrocarbons and OVOC species and their average concentrations are listed in Table 1 and Table 2, respectively. The total measured concentrations of hydrocarbons and OVOCs during the Changdao campaign were $16.0 \pm 9.1 \mathrm{ppb}$ and $12.7 \pm 8.1 \mathrm{ppb}$, respectively. The total concentrations of hydrocarbons are significantly lower than those measured in urban sites (e.g. Beijing) in the central eastern China region (Shao et al., 2011). Alkanes (including acetylene with a low reactivity) are the dominant contributors to hydrocarbon concentrations $(67.2 \%)$. The percentages of alkenes, aromatics in hydrocarbons concentrations are only $18.9 \%, 13.9 \%$, respectively. The average concentrations of isoprene, MVK and MACR were $0.01 \pm 0.01,0.02 \pm 0.01$ and $0.03 \pm 0.01$, respectively. This indicates that biogenic emissions were not important at the Changdao site during the campaign. The low concentrations of biogenic species are not surprising, since the measurement period was not the growing season of plants.

To investigate the influence of the Changdao site from regional transport, back trajectories of the Changdao site during the campaign are performed each hour (Fig. S2) using the HYbrid Single Particle Lagrangian Integrated Trajectory (HYSPLIT) (Draxler and Rolph, 2003). Cluster analysis to the back trajectories is conducted and a five-cluster solution is selected as the optimum solution (Fig. 1a), according to the relative changes of total spatial variance. Clusters \#2 and \#3 coming from the south and west are found to be the predominant back trajectory cluster during the campaign, accounting for $60 \%$ of the measurement period in total. Clusters \#2 and \#3 mainly received outflows from Tianjin, the eastern part of Hebei and most of Shandong, the regions with highdensity emissions. The mean concentrations of $\mathrm{CO}$ in the two 
Table 1. Mixing ratios and derived emission ratios of various NMHCs to CO during the period 2-25 April 2011 at Changdao (average \pm standard deviation).

\begin{tabular}{|c|c|c|c|c|c|}
\hline Species* & $\begin{array}{l}\text { Mixing ratios, } \\
\text { ppb }\end{array}$ & $\begin{array}{l}\text { Emission ratios } \\
\mathrm{ppb}^{-1} \mathrm{CO} \mathrm{m}^{-1} \mathrm{C}\end{array}$ & Species* & $\begin{array}{l}\text { Mixing ratios, } \\
\text { ppb }\end{array}$ & $\begin{array}{l}\text { Emission ratios } \\
\mathrm{ppb}^{-1} \mathrm{pm}^{-1} \mathrm{CO}\end{array}$ \\
\hline Ethane & $4.00 \pm 2.05$ & $7.73 \pm 0.64$ & Benzene & $0.99 \pm 0.63$ & $2.31 \pm 0.08$ \\
\hline Ethene & $1.79 \pm 1.46$ & $5.28 \pm 0.19$ & n-heptane & $0.07 \pm 0.06$ & $0.23 \pm 0.02$ \\
\hline Propane & $1.78 \pm 1.45$ & $4.54 \pm 0.46$ & Methylcyclohexane & $0.05 \pm 0.06$ & $0.20 \pm 0.02$ \\
\hline Propene & $0.30 \pm 0.28$ & $1.35 \pm 0.08$ & 2,3,4-TMpentane & $0.00 \pm 0.00$ & $0.01 \pm 0.00$ \\
\hline i-butane & $0.51 \pm 0.43$ & $1.22 \pm 0.10$ & 2-methylheptane & $0.02 \pm 0.02$ & $0.06 \pm 0.00$ \\
\hline n-butane & $0.86 \pm 0.92$ & $2.50 \pm 0.29$ & 3-methylheptane & $0.01 \pm 0.01$ & $0.03 \pm 0.00$ \\
\hline Acetylene & $1.85 \pm 1.28$ & $4.56 \pm 0.20$ & Toluene & $0.59 \pm 0.48$ & $1.85 \pm 0.10$ \\
\hline t-2-butene & $0.03 \pm 0.03$ & $0.05 \pm 0.01$ & n-Octane & $0.04 \pm 0.03$ & $0.11 \pm 0.01$ \\
\hline 1-butene & $0.14 \pm 0.14$ & $0.39 \pm 0.03$ & Ethylbenzene & $0.16 \pm 0.13$ & $0.56 \pm 0.03$ \\
\hline i-butene & $0.74 \pm 0.19$ & $1.00 \pm 0.10$ & $\mathrm{~m}+\mathrm{p}$-xylene & $0.19 \pm 0.21$ & $1.31 \pm 0.07$ \\
\hline c-2-butene & $0.03 \pm 0.02$ & $0.07 \pm 0.01$ & n-Nonane & $0.02 \pm 0.01$ & $0.07 \pm 0.00$ \\
\hline i-pentane & $0.52 \pm 0.43$ & $1.45 \pm 0.11$ & o-xylene & $0.07 \pm 0.06$ & $0.37 \pm 0.02$ \\
\hline n-pentane & $0.36 \pm 0.34$ & $0.99 \pm 0.09$ & Styrene & $0.02 \pm 0.03$ & $0.07 \pm 0.01$ \\
\hline 1,3-butadiene & $0.02 \pm 0.02$ & $0.10 \pm 0.01$ & i-propylbenzene & $0.01 \pm 0.00$ & $0.01 \pm 0.00$ \\
\hline 1-pentene & $0.01 \pm 0.01$ & $0.05 \pm 0.00$ & n-propylbenzene & $0.01 \pm 0.01$ & $0.03 \pm 0.00$ \\
\hline trans-2-pentene & $0.00 \pm 0.00$ & $0.00 \pm 0.00$ & m-ethyltoluene & $0.02 \pm 0.02$ & $0.08 \pm 0.01$ \\
\hline Isoprene & $0.01 \pm 0.01$ & $0.02 \pm 0.00$ & p-ethyltoluene & $0.01 \pm 0.01$ & $0.04 \pm 0.00$ \\
\hline cis-2-pentene & $0.00 \pm 0.00$ & $0.00 \pm 0.00$ & n-decane & $0.02 \pm 0.01$ & $0.06 \pm 0.00$ \\
\hline 2,2-dimethylbutane & $0.01 \pm 0.01$ & $0.02 \pm 0.00$ & 1,3,5-TMB & $0.01 \pm 0.01$ & $0.04 \pm 0.00$ \\
\hline 2,3-dimethylbutane & $0.03 \pm 0.04$ & $0.06 \pm 0.01$ & o-ethyltoluene & $0.01 \pm 0.01$ & $0.04 \pm 0.00$ \\
\hline 2-methylpentane & $0.14 \pm 0.11$ & $0.39 \pm 0.03$ & $1,2,4-\mathrm{TMB}$ & $0.03 \pm 0.02$ & $0.13 \pm 0.01$ \\
\hline Cyclopentane & $0.04 \pm 0.04$ & $0.12 \pm 0.01$ & 1,2,3-ТМB & $0.01 \pm 0.01$ & $0.05 \pm 0.00$ \\
\hline 3-methylpentane & $0.09 \pm 0.08$ & $0.29 \pm 0.02$ & Acetonitrile (m42) & $0.21 \pm 0.12$ & $0.50 \pm 0.02$ \\
\hline 1-hexene & $0.04 \pm 0.03$ & $0.09 \pm 0.01$ & Benzene (m79) & $0.55 \pm 0.36$ & $1.45 \pm 0.05$ \\
\hline n-hexane & $0.17 \pm 0.16$ & $0.53 \pm 0.04$ & Toluene (m93) & $0.57 \pm 0.51$ & $2.05 \pm 0.12$ \\
\hline 2,4-DMpentane & $0.02 \pm 0.01$ & $0.04 \pm 0.00$ & Styrene (m105) & $0.05 \pm 0.04$ & $0.08 \pm 0.01$ \\
\hline Methylcyclopentane & $0.08 \pm 0.08$ & $0.29 \pm 0.02$ & C8-aromatics (m107) & $0.42 \pm 0.39$ & $2.34 \pm 0.13$ \\
\hline 2-methylhexane & $0.03 \pm 0.03$ & $0.10 \pm 0.01$ & C9-aromatics (m121) & $0.14 \pm 0.10$ & $0.50 \pm 0.03$ \\
\hline Cyclohexane & $0.06 \pm 0.08$ & $0.19 \pm 0.02$ & Naphthalene (m129) & $0.09 \pm 0.08$ & $0.34 \pm 0.02$ \\
\hline 2,3-dimethylpentane & $0.02 \pm 0.02$ & $0.06 \pm 0.01$ & C10-aromatics (m135) & $0.07 \pm 0.06$ & $0.30 \pm 0.02$ \\
\hline 3-methylhexane & $0.05 \pm 0.03$ & $0.14 \pm 0.01$ & Monoterpenes (m137) & $0.07 \pm 0.06$ & $0.13 \pm 0.02$ \\
\hline 2,2,4-TMpentane & $0.00 \pm 0.00$ & $0.00 \pm 0.00$ & & & \\
\hline
\end{tabular}

* DM and TM indicate dimethyl- and trimethyl-, respectively. TMB is short for trimethylbenzene.

clusters were respectively $0.61 \mathrm{ppm}$ and $0.53 \mathrm{ppm}$, highest among the clusters. Clusters \#4 and \#5 came from the northeastern part of China and showed lowest $\mathrm{CO}$ mean concentrations. The periods in cluster \#4 and cluster \#5 were usually accompanied with low temperature and the invasion of a cold front (Fig. S3). The low CO concentrations in clusters \#4 and $\# 5$ are due to the combinations of these facts: (1) higher wind speeds facilitate dilution in the atmosphere, as indicated by the wind rose plot in Fig. 1b; (2) lower burden of emissions in northeastern China; (3) longer distance of transport from emission sources to the measurement site. Cluster \#1 traveled from the northwest and passed over Beijing, Tianjin and surrounding areas, resulting in a relatively high $\mathrm{CO}$ mean concentration $(0.51 \mathrm{ppm})$. Wind-dependent analysis of benzene and $\mathrm{CO}$ concentrations is also shown (Fig. 1c), and the results are generally consistent with the back trajectory analysis. The findings from back trajectory and wind analysis both in- dicate that the Changdao site mainly received emissions from the following provinces/municipalities: Shangdong, Hebei, Beijing, Tianjin and Liaoning. Thus, the Changdao site represents a receptor site of the regions surrounding the Bohai Sea during the measurement period.

\subsection{The relative importance of VOC oxidation pathways}

VOCs are mainly consumed by the reactions with $\mathrm{OH}$ radical, ozone and $\mathrm{NO}_{3}$ radical in the atmosphere (Atkinson and Arey, 2003). The VOC loss rate $\left(L_{\mathrm{VOC}}\right)$ in the atmosphere can be expressed by

$L_{\mathrm{VOC}}=\sum_{i}^{3} k \times[\mathrm{VOC}] \times[$ Oxidant $]$ 
Table 2. The parameters describing OVOC concentrations at Changdao.

\begin{tabular}{|c|c|c|c|c|c|c|}
\hline \multirow[t]{2}{*}{ Species } & \multirow{2}{*}{$\begin{array}{l}\text { Mixing ratios, } \\
\mathrm{ppb}\end{array}$} & ER OVOC & $\mathrm{ER}_{\text {precursor }}$ & $k_{\mathrm{OVOC}}$ & $k_{\text {precursor }}$ & \multirow{2}{*}{$\begin{array}{l}\text { Background } \\
\text { ppt }\end{array}$} \\
\hline & & \multicolumn{2}{|c|}{$\mathrm{ppb} \mathrm{ppm}^{-1} \mathrm{CO}$} & \multicolumn{2}{|c|}{$10^{-12} \mathrm{~cm}^{3}$ molec $^{-1} \mathrm{~s}^{-1}$} & \\
\hline Acetaldehyde & $0.63 \pm 0.44$ & $1.20 \pm 0.84$ & 8.33 & 15 & 3.49 & $47 \pm 25$ \\
\hline Propanal & $0.27 \pm 0.13$ & $0.25 \pm 0.05$ & 1.98 & 20 & 6.22 & $109 \pm 6$ \\
\hline n-Butanal & $0.11 \pm 0.04$ & $0.13 \pm 0.02$ & 5.72 & 24 & 0.53 & $57 \pm 3$ \\
\hline n-Pentanal & $0.04 \pm 0.02$ & $0.04 \pm 0.01$ & 0.73 & 28 & 1.85 & $27 \pm 1$ \\
\hline Acrolein & $0.09 \pm 0.06$ & $0.15 \pm 0.03$ & 0.31 & 18.3 & 22.16 & $23 \pm 3$ \\
\hline Acetone & $1.85 \pm 0.92$ & $1.57 \pm 0.37$ & 4.65 & 0.17 & 5.75 & $780 \pm 56$ \\
\hline MEK & $0.35 \pm 0.22$ & $0.47 \pm 0.08$ & 2.73 & 1.22 & 1.78 & $90 \pm 14$ \\
\hline 2-pentanone & $0.02 \pm 0.02$ & $0.02 \pm 0.01$ & 0.29 & 4.4 & 2.37 & $5 \pm 1$ \\
\hline 3-pentanone & $0.03 \pm 0.02$ & $0.01 \pm 0.01$ & 1.52 & 2 & 0.39 & $12 \pm 1$ \\
\hline Methanol & $5.67 \pm 4.80$ & $16.0 \pm 0.67$ & $0^{*}$ & 0.94 & $0^{*}$ & $156 \pm 290$ \\
\hline Formic acid & $2.28 \pm 1.02$ & $1.06 \pm 0.44$ & 5.44 & 0.4 & 7.58 & $1219 \pm 65$ \\
\hline Acetic acid & $0.77 \pm 0.76$ & $1.27 \pm 0.32$ & 2.64 & 0.8 & 7.54 & $0 \pm 0^{*}$ \\
\hline
\end{tabular}

* The values are found to be negative. The parameter was set to zero and fit was repeated.

[VOC] and [Oxidant] are mixing ratios of VOC species and the oxidants $\left(\mathrm{OH}\right.$ radical, ozone or $\mathrm{NO}_{3}$ radical), respectively. $k$ is the rate constant of VOC species with the oxidants (see Table S1). Since some OVOC species can also undergo photolysis in the atmosphere, photolysis frequencies are also incorporated in Eq. (1) for these OVOC species.

$\mathrm{OH}$ radical and $\mathrm{NO}_{3}$ radical were not measured at Changdao. $\mathrm{OH}$ radical concentration (in molecule $\mathrm{cm}^{-3}$ ) can be estimated from the parameterization method suggested by Ehhalt and Rohrer (2000):

$$
\begin{gathered}
{[\mathrm{OH}]=4.1 \times 10^{9} \times\left(J_{\mathrm{O} 1 \mathrm{D}}\right)^{0.83} \times\left(J_{\mathrm{NO} 2}\right)^{0.19}} \\
\times \frac{140 \times\left[\mathrm{NO}_{2}\right]+1}{0.41 \times\left[\mathrm{NO}_{2}\right]^{2}+1.7 \times\left[\mathrm{NO}_{2}\right]+1} .
\end{gathered}
$$

Here, $J_{\mathrm{O} 1 \mathrm{D}}$ and $J_{\mathrm{NO} 2}$ are measured photolysis frequency $\left(\mathrm{s}^{-1}\right)$ of ozone and $\mathrm{NO}_{2}$, respectively. $\left[\mathrm{NO}_{2}\right]$ is measured $\mathrm{NO}_{2}$ concentration (ppb). The values in the equation are obtained from measurement data with $\mathrm{NO}_{\mathrm{x}}$ concentrations $>1 \mathrm{ppb}$ during the POPCORN campaign at a rural site in Germany. The uncertainty of Eq. (2) to estimate $\mathrm{OH}$ concentration at Changdao is unknown. Calculation of $\mathrm{OH}$ concentrations using Eq. (2) at a suburban site (Yufa) near Beijing, a site with similar ranges of air compositions as Changdao (see values in Table 2 of Lu et al., 2013, Table 1 and Table S2), shows uncertainties within $50 \%$ (Zheng et al., 2011).

$\mathrm{NO}_{3}$ concentration could be determined by

$\left[\mathrm{NO}_{3}\right]$

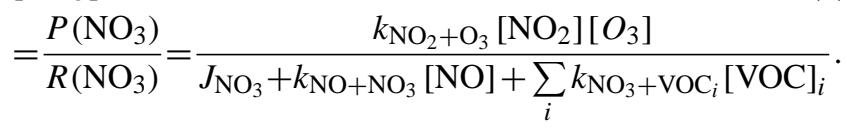

The derivation of this equation is based on the steadystate assumption of $\mathrm{NO}_{3}$ concentration in the atmosphere. $P\left(\mathrm{NO}_{3}\right)$ is the production rate of $\mathrm{NO}_{3}$, mainly from the reaction of $\mathrm{NO}_{2}$ with $\mathrm{O}_{3} . R\left(\mathrm{NO}_{3}\right)$ represents $\mathrm{NO}_{3}$ reactivity, which is composed by $\mathrm{NO}_{3}$ photolysis $\left(J_{\mathrm{NO}_{3}}\right)$, the reaction of
$\mathrm{NO}_{3}$ with $\mathrm{NO}\left(k_{\mathrm{NO}+\mathrm{NO}_{3}}[\mathrm{NO}]\right)$ and the reactions of $\mathrm{NO}_{3}$ with the measured VOC species $\left(\sum_{i} k_{\mathrm{NO}_{3}}+\mathrm{VOC}_{i}[\mathrm{VOC}]_{i}\right)$. The involved reactions, related parameters and uncertainties in the calculation of $\mathrm{NO}_{3}$ concentration are described in detail in the Supplement. Note that $\mathrm{NO}_{3}$ loss due to $\mathrm{N}_{2} \mathrm{O}_{5}$ hydrolysis is not accounted for in Eq. (3). Thus, $\mathrm{NO}_{3}$ concentrations calculated from Eq. (3) are upper limits and the calculation of $\mathrm{NO}_{3}$ contributions to VOC losses is also overestimated.

Diurnal variations of VOC loss rates due to the reactions with different oxidants are shown in Fig. S5. Reaction with $\mathrm{OH}$ radical is the dominant photochemical loss for alkanes and aromatics (e.g. m+p-xylene). Reactions with $\mathrm{NO}_{3}$ and ozone are insignificant for the loss rates of alkanes and aromatics. Since ozone can react with alkenes at significant rates, oxidation by ozone also contributes to the loss rates of alkenes. For example, reaction with ozone accounts for $21.2 \%$ of the $24 \mathrm{~h}$ averaged loss rate of ethene in Changdao. In contrast to anthropogenic hydrocarbons, the oxidation by $\mathrm{NO}_{3}$ radical is more important for the loss rates of isoprene and monoterpenes. Reaction with $\mathrm{NO}_{3}$ radical contributes to $25.7 \%$ and $63.2 \%$ of the $24 \mathrm{~h}$ averaged loss rates of isoprene and monoterpenes, respectively. For most OVOC species, reaction with $\mathrm{OH}$ radical is also the only significant contributor to OVOC loss rates in the Changdao campaign. Compared to $\mathrm{OH}$ oxidation, photolysis is only important to the loss rates of ketones (e.g. acetone and MEK). Photolysis accounts for $44 \%$ of the $24 \mathrm{~h}$ averaged loss rate of acetone.

The total loss rates of anthropogenic and biogenic hydrocarbons are calculated from individual species, and the diurnal variations of the total loss rates for the two classes of species are shown in Fig. 2. Oxidation by $\mathrm{OH}$ radical accounts for $69.3 \%$ of the $24 \mathrm{~h}$ averaged total loss rate of anthropogenic hydrocarbons, whereas the contribution from the reactions with $\mathrm{NO}_{3}$ radical and ozone are $27.3 \%$ and $3.3 \%$, respectively. Reaction with $\mathrm{NO}_{3}$ radical is the dominant 
contributor to loss rates of biogenic species (59.2\%). Reaction with $\mathrm{OH}$ radical only accounts for $22.0 \%$ of the loss rate of biogenic species. It should be emphasized that the estimation may overestimate $\mathrm{NO}_{3}$ contributions to biogenic species due to the uncertainties in calculation of $\mathrm{NO}_{3}$ concentrations.

\subsection{VOC evolution by using a parameterization method}

VOC evolutions in the atmosphere were characterized by a photochemical-age-based parameterization method. The first-order reaction relationship for VOCs reacting with $\mathrm{OH}$ radical was used to constrain the measured concentrations of NMHCs and OVOCs. This parameterization method has been applied in the northeastern US (de Gouw et al., 2005) and in Beijing (Yuan et al., 2012). There are several underlying assumptions in the parameterization method to describe VOC evolution at Changdao (de Gouw et al., 2005): (1) urban emissions are the dominant sources of VOCs sampled at the Changdao site; (2) the speciation of VOC emissions were the same in different parts of the influencing regions, and the magnitude of emissions is proportional to $\mathrm{CO}$; (3) the removal of VOCs is mainly due to the reaction with $\mathrm{OH}$; and (4) the photochemical age can be described by the measured ratio between two VOC species $(\mathrm{m}+\mathrm{p}$-xylene and ethylbenzene in this study). Considering that concentrations of biogenic species were low during the campaign (Sect. 3.1) and the influences from biomass burning and local coal burning were filtered out (Sect. 2), the only dominant VOC source is urban emissions (assumption 1). Note that urban emissions here include all of the activities that are considered as VOC emitters in/near urban areas; e.g. vehicle exhausts, domestic usage of fossil fuel and industry emissions adjoin to urban areas. Measurement in central eastern China showed that VOC concentration profiles are similar at several sites (Suthawaree et al., 2010, 2012), suggesting that the first part of assumption (2) is reasonable. The analysis in Sect. 3.2 shows that assumption (3) holds true at the Changdao site. The assumption (4) and the second part of assumption (2) will be investigated using alternative parameters in the following discussions.

Photochemical age $\Delta t$ was calculated from the measured concentration ratios of $m+p-x y l e n e$ to ethylbenzene:

$\Delta t=\frac{1}{[\mathrm{OH}]\left(k_{x}-k_{E}\right)} \times\left(\left.\ln \frac{[X]}{[E]}\right|_{t=0}-\ln \frac{[X]}{[E]}\right)$.

Here, $\frac{[X]}{[E]}$ and $\left.\frac{[X]}{[E]}\right|_{t=0}$ are the concentration ratios and initial emission ratios of $\mathrm{m}+\mathrm{p}$-xylene and ethylbenzene, respectively. $k_{x}$ and $k_{E}$ are the $\mathrm{OH}$ rate constants of $\mathrm{m}+\mathrm{p}-$ xylene $\left(18.9 \times 10^{-12} \mathrm{~cm}^{3}\right.$ molecule $\left.{ }^{-1} \mathrm{~s}^{-1}\right)$ and ethylbenzene $\left(7.0 \times 10^{-12} \mathrm{~cm}^{3}\right.$ molecule $\left.{ }^{-1} \mathrm{~s}^{-1}\right)$. [OH] is the averaged $\mathrm{OH}$ radical concentrations $\left(0.72 \times 10^{6}\right.$ molecule $\left.\mathrm{cm}^{-3}\right)$ calculated in from the empirical equation (Ehhalt and Rohrer, 2000) (Sect. 3.2). It should be noted that the uncertainty in the calculation of $[\mathrm{OH}]$ concentration from Eq. (2) will not affect the following VOC analysis, since the product of [OH] and $\Delta t$ (usually called $\mathrm{OH}$ exposure) is only required for cal-
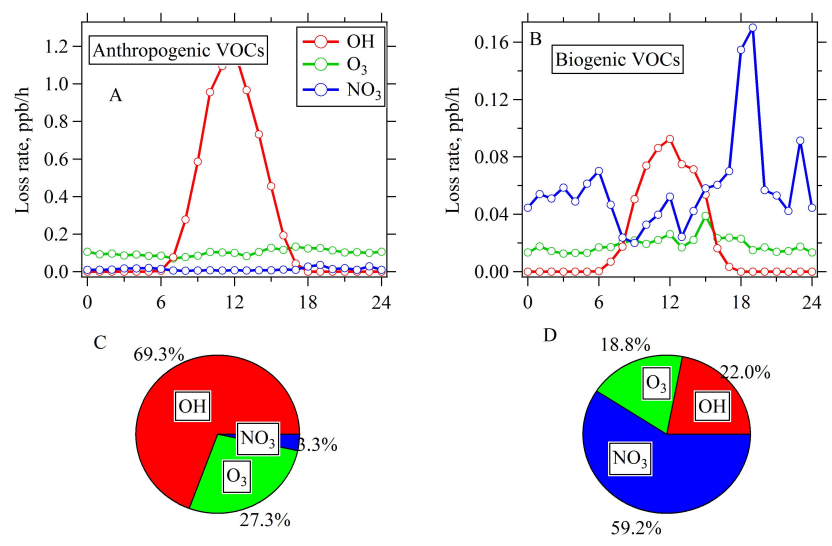

Fig. 2. Diurnal variations of loss rates of anthropogenic (A) and biogenic (B) VOCs from reactions with $\mathrm{OH}$ radical, $\mathrm{NO}_{3}$ radical and ozone. The fractions in $24 \mathrm{~h}$ averaged loss rates of anthropogenic (C) and biogenic (D) VOCs consumed by the three different oxidants.

culation in the equations. The initial emission ratio of $\mathrm{m}+\mathrm{p}-$ xylene to ethylbenzene was calculated from the ratios of the two species with the highest measurement concentrations, as shown in Fig. S6. The determined initial emission ratio of $\mathrm{m}+\mathrm{p}$-xylene to ethylbenzene is $2.2 \mathrm{ppb} \mathrm{ppb}^{-1}$, which is close to the largest concentrations ratios measured during the time period 0:00-6:00 LT during the Changdao campaign. The initial emission ratio is also comparable to the ratios in various source profiles of China (Liu et al., 2008) and the studies in Beijing (2.0) (Shao et al., 2011). Using an alternative ratio (o-xylene/ethylbenzene) to calculate photochemical age is also tested (see following discussions).

The concentrations of non-methane hydrocarbons (NMHCs) can be described by the following equation (de Gouw et al., 2005):

$$
\begin{aligned}
& {[\mathrm{NMHC}]=\mathrm{ER} \times\left([\mathrm{CO}]-[\mathrm{CO}]_{\mathrm{bg}}\right)} \\
& \quad \times \exp \left[-\left(k_{\mathrm{NMHC}}-k_{\mathrm{CO}}\right)[\mathrm{OH}] \Delta t\right] .
\end{aligned}
$$

Here, $[\mathrm{NMHC}]$ and $[\mathrm{CO}]$ are the concentrations of NMHCs and $\mathrm{CO}$, respectively. $[\mathrm{CO}]_{\mathrm{bg}}$ is the $\mathrm{CO}$ background concentration, which is determined from the intercept in the scatterplot of $\mathrm{CO}$ with benzene $(0.104 \mathrm{ppm}$, and $0.1 \mathrm{ppm}$ is used in the following analysis). $k_{\mathrm{NMHC}}$ and $k_{\mathrm{CO}}$ are the $\mathrm{OH}$ rate constant of NMHC and CO $\left(0.24 \times 10^{-12} \mathrm{~cm}^{3}\right.$ molecule $\left.{ }^{-1} \mathrm{~s}^{-1}\right)$, respectively. $[\mathrm{OH}]$ and $\Delta t$ are the $\mathrm{OH}$ radical concentrations and determined photochemical age. ER is the emission ratio of NMHCs to CO. Following the procedures in previous studies (de Gouw et al., 2005), all of the parameters in Eq. (5) are known except ER and $k_{\mathrm{NMHC}}$, which are obtained from fits to Eq. (5) to each VOC species.

The determined emission ratios of various NMHC species to $\mathrm{CO}$ are tabulated in Table 1. The uncertainties in calculating NMHC emission ratios from Eq. (5) come from measurement errors of VOCs species and $\mathrm{CO}$, and also from the 
estimation of photochemical age, $\mathrm{CO}$ background and the representativeness of $\mathrm{CO}$ as an urban tracer of VOCs. Several tests are conducted to investigate the influence of the uncertainties in calculated emission ratios, including using the o-xylene / ethylbenzene ratio $(\mathrm{O} / \mathrm{E})$ rather than the $\mathrm{m}+\mathrm{p}$ xyelne / ethylbenzene ratio (X/E) to estimate photochemical age, using acetylene rather than $\mathrm{CO}$ as the urban tracer, using higher and lower $\mathrm{CO}$ background concentrations $(0.07 \mathrm{ppm}$ and $0.13 \mathrm{ppm})$. The results from these tests are shown in Fig. S7 (B-D). The relative changes of using different CO background concentrations (-5\% to $6 \%$ ) and using acetylene as urban tracer (about $13 \%$ ) are relative small, whereas the relative changes between using $\mathrm{O} / \mathrm{E}$ and $\mathrm{X} / \mathrm{E}$ ratios to calculate photochemical age range from $-31 \%$ to $57 \%$ for various species $(90 \%$ of the species are in the range of $\pm 30 \%$ ). Adding up the measurement errors $(10 \%)$, the uncertainties of the calculated emission ratios are better than $50 \%$ for most VOC species.

The calculated emission ratios from Eq. (5) could be compared with those directly from the linear regression method without the consideration of chemical losses (Warneke et al., 2007), as shown in Fig. S8. Though emission ratios of inert hydrocarbons agree well between the two methods, emission ratios of highly reactive species are significantly underestimated by the traditional correlation method (as high as $70 \%$ ). The derived $k_{\mathrm{NMHC}}$ values compared well with those from the literature for the species with lower $k_{\mathrm{NMHC}}$ values than $\mathrm{m}+\mathrm{p}$-xylene (Fig. S6), consistent with the observations during NEAQS (de Gouw et al., 2005).

It is well known that PTR-MS measure the sum concentrations of $\mathrm{C} 8-, \mathrm{C} 9-$ and $\mathrm{C} 10$-aromatics in their specific channels. The measured concentrations of C8-, C9 and C10aromatics are also fitted using Eq. (50), even though Eq. (5) is intended to describe the evolution of a single hydrocarbon. Interestingly, the determined $\mathrm{C} 8$-aromatics emission ratio is $2.34 \pm 0.13 \mathrm{ppb} \mathrm{ppm}^{-1}$, which agrees well with the sum of the emission ratios of ethylbenzene, $\mathrm{m}+\mathrm{p}$-xylene and $\mathrm{o}-$ xylene measured from GC-MS/FID (2.24 $\left.\mathrm{ppb} \mathrm{ppm}^{-1}\right)$. The good agreement, at least partially, suggests that the sum concentration of several VOC species measured by PTR-MS can also be used to assess the contribution of these compounds to SOA formation in the following discussions, especially for the species not explicitly measured by GC-MS/FID (e.g. C10-aromatics).

Concentrations of OVOCs can be separated into primary emissions, secondary formation and background concentrations, as shown in the following equation (de Gouw et al., 2005):

$$
\begin{aligned}
& {[\mathrm{OVOC}]=\mathrm{ER}_{\mathrm{OVOC}} \times([\mathrm{CO}]-0.1)} \\
& \times \exp \left(-\left(k_{\mathrm{OVOC}}-k_{\mathrm{CO}}\right)[\mathrm{OH}] \Delta t\right)+\mathrm{ER}_{\text {precursor }} \\
& \times([\mathrm{CO}]-0.1) \times \frac{k_{\text {precursor }}}{k_{\mathrm{OVOC}}-k_{\text {precursor }}} \\
& \times \frac{\exp \left(-k_{\text {precursor }}[\mathrm{OH}] \Delta t\right)-\exp \left(-k_{\mathrm{OVOC}}[\mathrm{OH}] \Delta t\right)}{\exp \left(-k_{\mathrm{CO}}[\mathrm{OH}] \Delta t\right.} \\
& +[\mathrm{bg}] .
\end{aligned}
$$

Here, $[\mathrm{OVOC}]$ and $[\mathrm{CO}]$ are concentrations of OVOCs and CO. $k_{\mathrm{OVOC}}, k_{\mathrm{CO}}$ and $k_{\text {precursor }}$ are the $\mathrm{OH}$ rate constants of OVOC, CO and OVOC precursors, respectively. ER $\mathrm{OVOC}_{\mathrm{OC}}$ and $\mathrm{ER}_{\text {precursor }}$ are emission ratios of OVOC and OVOC precursor to $\mathrm{CO}$, respectively. The contributions of biogenic emissions to OVOCs were neglected in this study, since the concentrations of isoprene, MVK and MACR were quite low during the campaign $(<0.1 \mathrm{ppb})$. Unrealistic results were obtained from the fits if biogenic sources were included in Eq. (6). The parameters of ER $\mathrm{EVOC}_{\mathrm{O}}, \mathrm{ER}_{\text {precursor }}, k_{\text {precursor }}$ and $[\mathrm{bg}]$ in Eq. (6) are unknown and they are determined from least squares fits. Table 2 tabulates the parameters that describe OVOC concentrations in the Changdao campaign. Table 3 shows the correlation coefficients between measured OVOC concentrations and calculated values using fitted unknown parameters in Eq. (6). Correlation coefficients of various OVOCs are in the range of $0.70-0.88$.

The source apportionment results of OVOCs are also shown in Table 3. Previous studies have proposed that the different times of photochemical aging in the atmosphere should be considered when OVOC allocation results are compared in different campaigns. The average $\mathrm{OH}$ exposure at Changdao is $6.1 \pm 2.7$ molecule $\mathrm{cm}^{-3} \mathrm{~s}$, suggesting that air masses are more aged than those at the urban site in Beijing (Yuan et al., 2012), but less processed than those in the NEAQS 2002 study (de Gouw et al., 2005). The ratio of anthropogenic secondary fraction to primary fraction in acetaldehyde concentrations in the campaigns of Beijing, Changdao and the northeastern US are 0.6, 1.8 and 5.7, respectively. We can observe that aged air mass corresponds with higher ratio of secondary fraction to primary fraction. It is consistent with expected behavior of a highly reactive aldehyde in the atmosphere: primary emissions are quickly depleted by photochemistry and secondary formation starts to dominate the concentration.

\subsection{Comparison of VOC emission ratios with other regions and emission inventory data}

Emission ratios of VOCs to $\mathrm{CO}$ represent emission characteristics of VOCs in a specific region, specifically the regions surrounding Bohai Sea (Shandong, Hebei, Beijing, Tianjin and Liaoning) in this study. The calculated emission ratios in Sect. 3.3 should be viewed as the average emission characteristics from regional urban sources in the spring. Yuan et 
Table 3. Correlation coefficients $(R)$ between calculated and measured OVOC concentrations and the contributions of various sources to OVOC concentrations.

\begin{tabular}{lrrrr}
\hline Species & $R$ & $\begin{array}{r}\text { Primary } \\
\text { emission, \% }\end{array}$ & $\begin{array}{r}\text { Secondary } \\
\text { formation, \% }\end{array}$ & $\begin{array}{r}\text { Background, } \\
\%\end{array}$ \\
\hline Acetaldehyde & 0.88 & 33.1 & 59.4 & 7.5 \\
Propanal & 0.83 & 12.8 & 46.4 & 40.7 \\
n-Butanal & 0.78 & 13.9 & 32.6 & 53.5 \\
n-Pentanal & 0.70 & 8.6 & 20.4 & 61.0 \\
Acrolein & 0.80 & 24.9 & 49.3 & 25.9 \\
Acetone & 0.80 & 32.0 & 27.0 & 41.0 \\
MEK & 0.80 & 46.9 & 28.2 & 24.9 \\
2-pentanone & 0.81 & 23.7 & 53.5 & 22.8 \\
3-pentanone & 0.74 & 15.0 & 43.0 & 42.0 \\
Methanol & 0.79 & 97.4 & 0 & 2.6 \\
Formic acid & 0.78 & 17.2 & 31.3 & 51.5 \\
Acetic acid & 0.74 & 57.3 & 42.7 & 0 \\
\hline
\end{tabular}

al. (2012) reported emission ratios of VOCs in Beijing using a similar method based on measurement at an urban site. Thus, comparison between emission ratios determined in the two studies (Fig. 3) will be helpful in understanding the seasonal variations of source emissions. Reported emission ratios of other regions in the literature are also interesting to compare with the results obtained in this study. The available datasets (accessed in December 2012) are the northeastern US (Warneke et al., 2007), Mexico City (Bon et al., 2011) and Tokyo (Shirai et al., 2007). Note that emission ratios in the northeastern US are determined using the photochemicalage-based parameterization method, whereas the linear regression method was used in the datasets of Mexico City and Tokyo.

As shown in Fig. 3, emission ratios of alkanes and alkenes at Changdao are compared well with those in Beijing, whereas emission ratios of aromatics are significantly higher in Beijing. Difference of aromatics may be due to the higher emissions from solvent use in the summer season during the Beijing campaign. In contrast to Beijing, emission ratios of alkenes and aromatics are similar between Changdao and the northeastern US, but emission ratios of alkanes are larger in the northeastern US. The results are consistent with the findings from the comparisons between Beijing and the northeastern US (Yuan et al., 2012). Though comparable emission ratios for some hydrocarbons between Mexico City and Changdao are obtained, emission ratios for most hydrocarbons are larger in Mexico City, which may be attributable to the combined effects of liquified petroleum gas (LPG) emissions, industrial emissions and combustion efficiencies of vehicle fleet (Bon et al., 2011; Apel et al., 2010). Higher emission ratios of toluene and $\mathrm{C} 3-\mathrm{C} 4$ alkanes are observed in Tokyo than those in Changdao, mainly due to the emissions from solvent use and LPG use (Parrish et al., 2009; Shirai et al., 2007), respectively.

Figure 4 shows emission ratios of acetaldehyde, propanal, acetone and MEK versus $\mathrm{CO}$ in the Changdao campaign
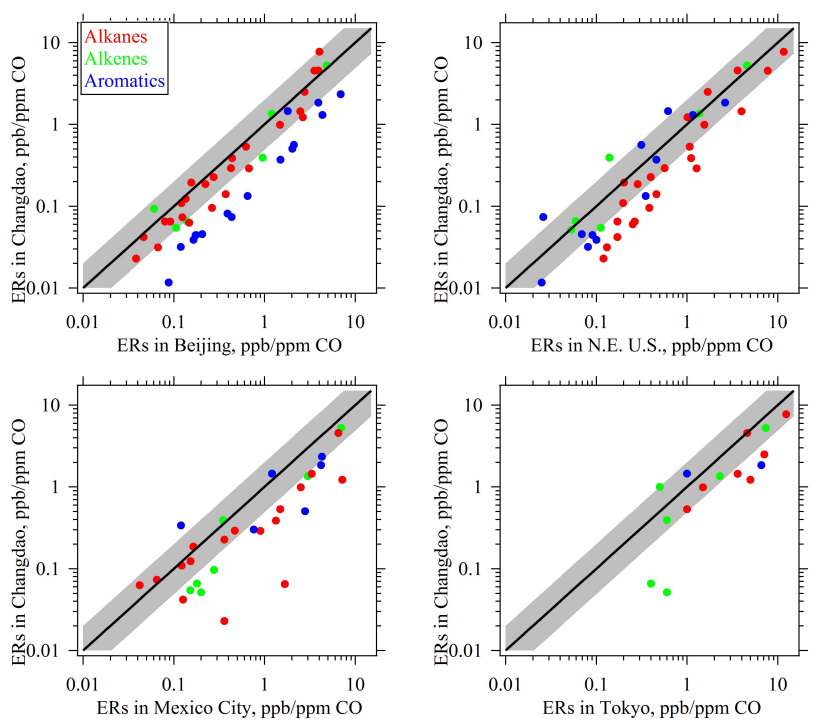

Fig. 3. Comparison of emission ratios of NMHCs to $\mathrm{CO}$ determined at Changdao with those obtained in Beijing (Yuan et al., 2012), the northeastern US (Warneke et al., 2007), Mexico City (Bon et al., 2011) and Tokyo (Shirai et al., 2007). The black lines indicate the 1 : 1 relationship, and the gray areas show agreements within a factor of two.

along with the results in other studies. Emission ratios from tunnel experiments (Ban-Weiss et al., 2008; Kristensson et al., 2004) are also shown in the shaded gray areas of the graphs. The two studies are selected for comparison, since they reported emission factors of both carbonyls and CO. Emission ratios of the four OVOC species obtained in Changdao generally fall in the ranges of reported values from the several field campaigns in Beijing, the northeastern US and Mexico City. However, some large discrepancies can be observed among the different campaigns. Emission ratios of propanal in Changdao and Beijing are lower than those in the US by a factor of 5-10. The large difference for propanal is unknown. It may be due to different emission sources of this species or controlling technologies in the sources between China and the US. Another possible reason for this is the large uncertainties in determining emission ratios of OVOCs (Warneke et al., 2007). Even though there are some discrepancies among the field campaigns in different regions, emission ratios of OVOCs from field campaigns are significantly larger than those in vehicle emissions, as illustrated in Fig. 4. It indicates that other non-vehicle sources may be important contributors to OVOC emissions. These sources may include painting application and cleaning products (Langford et al., 2010; Velasco et al., 2005). Limited information about emissions of OVOCs is available for these non-vehicle sources (Niedojadlo et al., 2007).

Furthermore, emission ratios from field campaigns could also be compared with the values in emission inventory data, which is an independent method to evaluate the accuracies of 

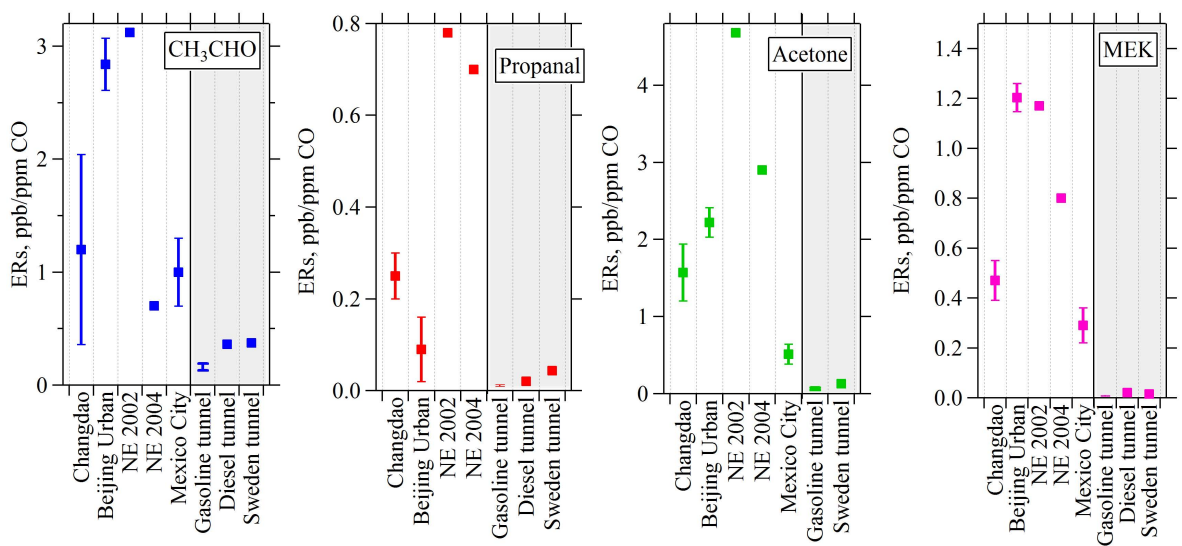

Fig. 4. Comparison of emission ratios of selected OVOC species in Changdao and those reported in Beijing (Yuan et al., 2012), the northeastern US in 2002 and 2004 (Warneke et al., 2007) and Mexico City (Bon et al., 2011). Emission ratios determined from tunnel experiments, including gasoline and diesel vehicle emissions in California (Ban-Weiss et al., 2008) and the results from a tunnel in Sweden (Kristensson et al., 2004), are shown in the shaded gray areas of the graph.
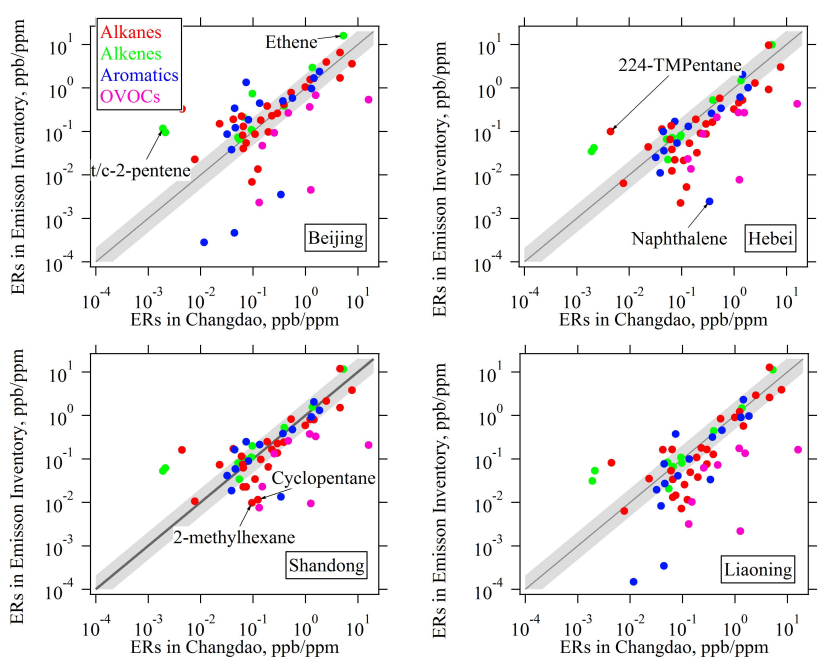

Fig. 5. Comparisons of emission ratios of VOCs to CO determined in the Changdao campaign with those in emission inventory data of the four surrounding provinces (Beijing, Hebei, Shandong and Liaoning) (Zhang et al., 2009). The black lines indicate the $1: 1$ relationship, and the gray areas show agreements within a factor of two.

VOC emission inventories. Figure 5 demonstrates the correlations of VOC emission ratios to CO determined in Changdao with those in the latest VOC emission inventory for the surrounding provinces (Beijing, Hebei, Liaoning and Shandong) (Zhang et al., 2009). The selected emission inventory established for INTEX-B is the most widely used inventory for China (Zhang et al., 2009). Emissions of CO in this inventory have been examined by top-down approaches and good agreements were obtained (Zhang et al., 2009). Emission ratios of most hydrocarbons in the Changdao campaign show agreements with those in the emission inventory within a factor of 2. In view of large uncertainties in the compilation of the emission inventory data (stated uncertainty of total VOCs emissions in China is $68 \%$ and uncertainties of individual species would be higher), the results are unexpected. The high quality of individual NMHC emission inventories may be attributed to the application of local established VOC source profiles (Liu et al., 2008) in VOC speciation of Zhang's inventory. However, the emissions of some hydrocarbons are obviously overestimated (e.g. ethene and trans/cis-2-pentene and 2,2,4-trimethylpentane) or underestimated (e.g. cyclopentane, 2-methylhexane and naphthalene) in the emission inventory. In contrast to hydrocarbons, emissions of OVOC emissions are significantly underestimated in the emission inventory. Failure of characterization of OVOC emissions in the inventory have also been inferred from field measurements in the northeastern US (Warneke et al., 2007) and flux measurements in urban areas (Langford et al., 2009, 2010). The possible reason is the dominance of poorly known diffusion sources in the primary emissions of OVOCs, as discussed above.

\subsection{Parameterization of organic aerosol (OA) concentrations}

The measured concentrations of organic aerosol (OA) are also separated into primary emissions, secondary formation and background concentrations (de Gouw et al., 2005, 2008):

$$
\begin{aligned}
& {[\mathrm{OA}]=\mathrm{ER}_{\mathrm{OA}} \times([\mathrm{CO}]-0.1) \times \frac{\exp \left(L_{\mathrm{OA}} \Delta t\right)}{\exp \left(-k_{\mathrm{CO}}[\mathrm{OH}] \Delta t\right)}} \\
& +\mathrm{ER}_{\text {precursor }} \times Y_{\mathrm{OA}} \times([\mathrm{CO}]-0.1) \times \frac{P_{\mathrm{OA}}}{L_{\mathrm{OA}}-P_{\mathrm{OA}}} \\
& \times \frac{\exp \left(-P_{\mathrm{OA}} \Delta t\right)-\exp \left(-L_{\mathrm{OA}} \Delta t\right)}{\exp \left(-k_{\mathrm{CO}}[\mathrm{OH}] \Delta t\right)}+[\mathrm{bg}] .
\end{aligned}
$$


In this equation, $\mathrm{ER}_{\mathrm{OA}}$ and $\mathrm{ER}_{\text {precursor }}$ are emission ratios of $\mathrm{OA}$ and $\mathrm{OA}$ precursors to CO. $L_{\mathrm{OA}}$ and $P_{\mathrm{OA}}$ are the loss and formation rates of OA. $Y_{\mathrm{OA}}$ is the yield of SOA precursor to form OA. The other parameters are the same as those in the equation of OVOCs. The unknown parameters are ER $\mathrm{OA}$, $\mathrm{ER}_{\text {precursor }} \times Y_{\mathrm{OA}}, L_{\mathrm{OA}}, P_{\mathrm{OA}}$ and $[\mathrm{bg}]$. Due to the coupling between the linear term and exponent terms in the equation, the initial fits are rather unstable. To overcome this problem, a number of $L_{\mathrm{OA}}$ values are set and fits are repeated for each $L_{\mathrm{OA}}$ value. After holding $L_{\mathrm{OA}}$ value, the fits are similar to the calculation of OVOCs. $L_{\mathrm{OA}}$ values (unit is $\mathrm{h}^{-1}$ ) tried in this study were derived from the possible lifetime of $\mathrm{OA}\left(\tau_{\mathrm{OA}}\right.$, unit is day) in the atmosphere from this equation:

$L_{\mathrm{OA}}=\frac{1}{\tau_{\mathrm{OA}} \times 24}$.

The lifetime of OA is affected by many factors, including size distribution, solubility of OA and also the mixing states of OA with other components (Millet et al., 2004). The determined OA lifetimes in the atmosphere are in the range of 3-10 days (Millet et al., 2004; Koch, 2001). Thus, OA lifetimes are changed from 1 day to 10 days with a step of half day, and the corresponding $L_{\mathrm{OA}}$ values were calculated. As OA lifetimes varied from 3 to 10 days, corresponding to $L_{\mathrm{OA}}$ values from $0.042 \mathrm{~h}^{-1}$ to $0.017 \mathrm{~h}^{-1}$, the fitted results of the parameters are quite stable (Fig. S9). The values of $\mathrm{ER}_{\mathrm{OA}}$ fluctuated from $14.3 \mu \mathrm{g} \mathrm{m}^{-3} \mathrm{ppm}^{-1}$ to $15.1 \mu \mathrm{g} \mathrm{m}^{-3} \mathrm{ppm}^{-1}$ and the background concentrations are in the range of 4.25$4.28 \mu \mathrm{g} \mathrm{m}^{-3}$. The allocated fractions of $\mathrm{OA}$ concentrations to the three parts also changed little with varying $L_{\mathrm{OA}}$ values (Fig. S10). The unstable values for aerosol lifetimes between 1-3 days may reflect these assumed aerosol lifetimes are too small compared to real conditions.

To represent the average results, we choose the fitted results associated with an OA lifetime of 6 days $\left(L_{\mathrm{OA}}\right.$ value is $\left.0.00694 \mathrm{~h}^{-1}\right)$. The determined $\mathrm{ER}_{\mathrm{OA}}$ is $14.9 \mu \mathrm{g} \mathrm{m}^{-3} \mathrm{ppm}^{-1}$, which is well in the range of POA/CO emission ratios reported in the literature (de Gouw and Jimenez, 2009) and it is quite close to the values obtained in Tokyo (Takegawa et al., 2006). The background concentration of OA is determined to $4.26 \mu \mathrm{g} \mathrm{m}^{-3}$. The time series of measured and calculated OA concentrations using the fitted results are shown in Fig. 6. Correlation coefficient $(R)$ between measured and calculated OA concentrations is 0.794 , which means that about $64 \%$ of OA concentration variability is described by Eq. (7). The fractions from primary emission and secondary formation are $38 \%$ and $29 \%$, respectively. OA/CO ratio increase to $29.6 \mu \mathrm{g} \mathrm{m}^{-3} \mathrm{ppm}^{-1}$ after $50 \mathrm{~h}$ of photochemical processing, with an enhancement of $18.8 \mu \mathrm{g} \mathrm{m}^{-3} \mathrm{ppm}^{-1}$ from secondary formation. Note that $\mathrm{OA} / \mathrm{CO}$ from primary emissions has decreased to $10.8 \mathrm{\mu g} \mathrm{m}^{-3} \mathrm{ppm}^{-1}$ after $50 \mathrm{~h}$ processing, due to the consideration of OA lifetime (6 days).

\subsection{Contributions of VOC oxidations to SOA formation}

Based on the evolution parameterization relationship of the VOCs/CO ratio with photochemical age, the ratio of consumed concentration to $\mathrm{CO}\left(\mathrm{NMHC}_{i, \text { consumed in }}\right.$ $\mu \mathrm{g} \mathrm{m}^{-3} \mathrm{ppm}^{-1} \mathrm{CO}$ ) could be determined by this equation:

$\mathrm{NMHC}_{i, \text { consumed }}=\mathrm{ER}_{i} \times\left(1-\exp \left(-k_{i, \mathrm{OH}}[\mathrm{OH}] \Delta t\right)\right)$.

Here, $\mathrm{ER}_{i}$ is the emission ratios of NMHCs versus CO expressed in the unit of $\mu \mathrm{g} \mathrm{m}^{-3} \mathrm{ppm}^{-1}$. Emission ratios in mass unit are calculated from the emission ratios in volume unit in Sect. 3.2. The $\mathrm{ER}_{i}$ values in the mass unit for selected hydrocarbons are tabulated in Table $4 . k_{i, \mathrm{OH}}$ is the $\mathrm{OH}$ rate constant of hydrocarbons determined from the fit of NMHCs. Thus, SOA produced from VOC oxidation $\left(\mathrm{SOA}_{\mathrm{cal}}\right)$ can be calculated by this equation:

$\mathrm{SOA}_{\mathrm{cal}}=\sum_{i} \mathrm{NMHC}_{i, \text { consumed }} \times Y_{i}$.

Here, $Y_{i}$ is the SOA yield of various hydrocarbons determined from chamber studies. Note that the unit of $\mathrm{SOA}_{\mathrm{cal}}$ is $\mu \mathrm{g} \mathrm{m}^{-3} \mathrm{ppm}^{-1} \mathrm{CO}$, meaning SOA formation from VOC oxidations at $1 \mathrm{ppm} \mathrm{CO}$ emissions.

SOA yields of VOCs have been expressed using an empirical relationship based on gas-particle partitioning of two semi-volatile products (Odum et al., 1996):

$Y=M_{0} \sum_{i}^{2} \frac{\alpha_{i} K_{\mathrm{om}, i}}{1+M_{0} K_{\mathrm{om}, i}}=M_{0} \sum_{i}^{2} \frac{\alpha_{i}}{M_{0}+c_{i}^{*}}$.

$M_{0}$ is the mass of organic aerosol. $\alpha_{i}$ and $c_{i}^{*}$ are the fitted results for the two-product relationship from chamber studies. $c_{i}^{*}$ is the effective saturation concentration of the oxidation products, and $\alpha_{i}$ is the mass stoichiometric coefficients of the product $i$. SOA yield of VOCs can be affected by ambient temperature, due to temperature dependence of $c_{i}^{*}$. This temperature dependence of SOA yield is accounted for by the Clausius-Clapeyron equation (Dzepina et al., 2009).

Literature studies show that SOA yields of hydrocarbons heavily depend on $\mathrm{NO}_{\mathrm{x}}$ levels, mainly due to the competition reactions of $\mathrm{RO}_{2}$ radical with $\mathrm{NO}$ and $\mathrm{HO}_{2}$ radical $(\mathrm{Ng}$ et al., 2007). SOA yields of most aromatics under low- $\mathrm{NO}_{\mathrm{x}}$ conditions are significantly higher than those under high- $\mathrm{NO}_{\mathrm{x}}$ conditions ( $\mathrm{Ng}$ et al., 2007). The branching ratios of $\mathrm{RO}_{2}$ radical reactions with $\mathrm{NO}$ and $\mathrm{HO}_{2}$ radicals were used to account for the $\mathrm{NO}_{\mathrm{x}}$ dependence of SOA formation (Bahreini et al., 2009; Henze et al., 2008). Preliminary results from a box model show that $\mathrm{RO}_{2}$ radicals are dominantly consumed by $\mathrm{NO}$, due to the large concentration of NO in the campaign. In this study, we separately calculated SOA formed from VOC oxidation under low- $\mathrm{NO}_{\mathrm{x}}$ and high- $\mathrm{NO}_{\mathrm{x}}$ conditions, and the results represent the higher and lower limits of SOA formation from VOC oxidations. Anthropogenic VOC species that can contribute SOA formation in this study are aromatics, > C8 alkanes and cycloalkanes, as tabulated in Table 4 . 
Table 4. Emission ratios of various VOC species, the percentages of reacted VOCs after $50 \mathrm{~h}$ photochemical reactions, SOA yields and the SOA masses formed after $50 \mathrm{~h}$ reactions.

\begin{tabular}{|c|c|c|c|c|c|c|c|}
\hline \multirow[t]{2}{*}{ Species $^{\mathrm{a}}$} & \multirow{2}{*}{$\begin{array}{l}\text { ERs, } \\
\mu \mathrm{g} \mathrm{m}^{-3} \mathrm{ppm}^{-1} \mathrm{CO}\end{array}$} & \multirow{2}{*}{$\begin{array}{l}\text { Reacted percent } \\
\text { at } 50 \mathrm{~h}, \%\end{array}$} & \multicolumn{2}{|c|}{ Yields } & \multicolumn{2}{|c|}{ SOA formed, $\mu \mathrm{g} \mathrm{m}^{-3} \mathrm{ppm}^{-1} \mathrm{CO}$} & \multirow[t]{2}{*}{ Notes } \\
\hline & & & Low- $\mathrm{NO}_{\mathrm{x}}$ & High- $\mathrm{NO}_{\mathrm{X}}{ }^{\mathrm{b}}$ & Low-NO $\mathrm{N}_{\mathrm{x}}$ & High- $\mathrm{NO}_{\mathrm{x}}$ & \\
\hline n-heptane & 1.02 & 47.7 & 0.009 & 0.009 & 0.004 & 0.004 & Lim and Ziemann (2009) \\
\hline n-octane & 0.56 & 52.5 & 0.041 & 0.041 & 0.012 & 0.011 & Lim and Ziemann (2009) \\
\hline n-nonane & 0.42 & 59.8 & 0.080 & 0.08 & 0.020 & 0.020 & Lim and Ziemann (2009) \\
\hline n-decane & 0.40 & 57.3 & 0.146 & 0.146 & 0.034 & 0.033 & Lim and Ziemann (2009) \\
\hline 2,4-DMpentane & 0.19 & 10.8 & 0.009 & 0.009 & 0.0002 & 0.0002 & n-heptane value \\
\hline 2,3-DMpentane & 0.27 & 40.5 & 0.009 & 0.009 & 0.001 & 0.001 & n-heptane value \\
\hline 3-methylhexane & 0.63 & 29.1 & 0.009 & 0.009 & 0.002 & 0.001 & n-heptane value \\
\hline 2,2,4-TMpentane & 0.02 & 32.9 & 0.041 & 0.041 & 0.0003 & 0.0003 & n-octane value \\
\hline 2,3,4-TMpentane & 0.04 & 54.8 & 0.041 & 0.041 & 0.001 & 0.001 & n-octane value \\
\hline 2-methylheptane & 0.33 & 52.7 & 0.041 & 0.041 & 0.007 & 0.007 & n-octane value \\
\hline 3-methylheptane & 0.16 & 53.3 & 0.041 & 0.041 & 0.003 & 0.003 & n-octane value \\
\hline Cyclopentane & 0.39 & 28.6 & 0.040 & 0.04 & 0.004 & 0.004 & cyclohexane value \\
\hline Methylcyclopentane & 1.10 & 58.8 & 0.040 & 0.04 & 0.026 & 0.025 & cyclohexane value \\
\hline Methylcyclohexane & 0.85 & 67.0 & 0.121 & 0.121 & 0.069 & 0.069 & cycloheptane value \\
\hline Benzene & 8.04 & 11.6 & 0.37 & 0.263 & 0.347 & 0.247 & $\mathrm{Ng}$ et al. (2007) \\
\hline Toluene & 7.60 & 39.2 & 0.30 & 0.12 & 0.894 & 0.359 & $\mathrm{Ng}$ et al. (2007) \\
\hline Ethylbenzene & 2.66 & 56.1 & 0.36 & 0.072 & 0.536 & 0.107 & m-xylene value \\
\hline $\mathrm{m}+\mathrm{p}$-xylene & 6.18 & 92.0 & 0.36 & 0.072 & 2.049 & 0.41 & $\mathrm{Ng}$ et al. (2007) \\
\hline o-xylene & 1.75 & 85.9 & 0.36 & 0.072 & 0.542 & 0.108 & m-xylene value \\
\hline Styrene & 0.34 & 68.3 & 0.36 & 0.072 & 0.084 & 0.016 & m-xylene value \\
\hline i-propylbenzene & 0.06 & 55.9 & 0.36 & 0.072 & 0.013 & 0.003 & m-xylene value \\
\hline n-propylbenzene & 0.17 & 51.4 & 0.36 & 0.072 & 0.032 & 0.006 & m-xylene value \\
\hline m-ethyltoluene & 0.44 & 75.4 & 0.36 & 0.072 & 0.118 & 0.023 & m-xylene value \\
\hline p-ethyltoluene & 0.24 & 68.7 & 0.36 & 0.072 & 0.056 & 0.011 & m-xylene value \\
\hline $1,3,5-\mathrm{TMB}$ & 0.24 & 78.2 & 0.36 & 0.072 & 0.067 & 0.013 & m-xylene value \\
\hline o-ethyltoluene & 0.21 & 58.2 & 0.36 & 0.072 & 0.044 & 0.008 & m-xylene value \\
\hline 1,2,4-TMB & 0.71 & 80.7 & 0.36 & 0.072 & 0.208 & 0.041 & m-xylene value \\
\hline 1,2,3-TMB & 0.24 & 75.2 & 0.36 & 0.072 & 0.066 & 0.013 & m-xylene value \\
\hline C10-aromatics & 1.81 & 72.6 & 0.36 & 0.072 & 0.472 & 0.094 & m-xylene value \\
\hline
\end{tabular}

a DM, TM and TMB indicate dimethyl-, trimethyl- and trimethylbenzene.

b Calculated from $M_{0}=15 \mu \mathrm{g} \mathrm{m}^{-3}$ and $T=10^{\circ} \mathrm{C}$.

Chamber studies showed that SOA yields of aromatics under high- $\mathrm{NO}_{\mathrm{x}}$ conditions can be described by the two-product relationship, whereas SOA yields under low- $\mathrm{NO}_{\mathrm{x}}$ conditions are constant numbers, independent of organic aerosol mass and temperature (Ng et al., 2007). Due to the lack of parameters in the two-product relationship and $\mathrm{NO}_{\mathrm{x}}$ dependence information for alkanes and cycloalkanes in the literature, SOA yields of these compounds under both high- $\mathrm{NO}_{\mathrm{x}}$ and low- $\mathrm{NO}_{\mathrm{x}}$ conditions are directly adapted from Lim and Ziemann (2009). SOA yields of VOC species without reported information in the literature are derived from species with similar molecular structures or carbon number (see details in Table 4).

Mass and temperature dependences of SOA yields are only considered for aromatics under high- $\mathrm{NO}_{\mathrm{x}}$ conditions. The average OA concentration during the Changdao campaign was $14.5 \pm 8.8 \mu \mathrm{g} \mathrm{m}^{-3}$, and more than $99.8 \%$ of OA concentrations were less than $50 \mu \mathrm{g} \mathrm{m}^{-3}$ (Fig. S11). The average temperature during the campaign was $9.9 \pm 3.8^{\circ} \mathrm{C}$, with a maximum and minimum of $1.1^{\circ} \mathrm{C}$ and $21.7^{\circ} \mathrm{C}$, respectively. Since SOA yield has a positive dependence on or- ganic aerosol mass and a negative dependence on temperature, maximum of organic mass and minimum of temperature are also used to construct different scenarios for calculating SOA yields of aromatics under high- $\mathrm{NO}_{\mathrm{x}}$ conditions. The four scenarios are $M_{0}=15 \mu \mathrm{g} \mathrm{m}^{-3}$ and $T=10^{\circ} \mathrm{C} ; M_{0}=50$ $\mu \mathrm{g} \mathrm{m}^{-3}$ and $T=0^{\circ} \mathrm{C} ; M_{0}=15 \mu \mathrm{g} \mathrm{m}^{-3}$ and $T=0^{\circ} \mathrm{C}$; and $M_{0}=50 \mu \mathrm{g} \mathrm{m}^{-3}$ and $T=10^{\circ} \mathrm{C}$, as shown in Table S3. The first scenario, calculated from averaged values, will be used for the comparison with low- $\mathrm{NO}_{\mathrm{x}}$ conditions in the following discussion. The calculated SOA yields for selected aromatic species under high- $\mathrm{NO}_{\mathrm{x}}$ conditions are also tabulated in Table S3.

The sixth and seventh columns of Table 4 show the SOA formed from each VOC species after $50 \mathrm{~h}$ transport under low- $\mathrm{NO}_{\mathrm{x}}$ and high- $\mathrm{NO}_{\mathrm{x}}$ conditions, respectively. Aromatics are the dominant contributors to the SOA formation in the measured VOC species. Aromatics account for $97.5 \%$ and $91.9 \%$ of the total SOA formation from measured VOCs under low- $\mathrm{NO}_{\mathrm{x}}$ and high- $\mathrm{NO}_{\mathrm{x}}$ conditions, respectively. The main SOA precursors are benzene, toluene, $\mathrm{m}+\mathrm{p}$-xylene, $\mathrm{o}$ xylene, ethylbenzene and naphthalene. Figure 7 shows the 
correlation of SOA calculated from VOC oxidations and SOA determined from AMS measurements under both high$\mathrm{NO}_{\mathrm{x}}$ and low- $\mathrm{NO}_{\mathrm{x}}$ conditions. SOA formation determined from VOC oxidation after $50 \mathrm{~h}$ are $2.0 \mu \mathrm{g} \mathrm{m}^{-3} \mathrm{ppm}^{-1}$ and $6.5 \mu \mathrm{g} \mathrm{m}^{-3} \mathrm{ppm}^{-1}$ under high- $\mathrm{NO}_{\mathrm{x}}$ and low- $\mathrm{NO}_{\mathrm{x}}$ conditions, respectively. It is obvious that SOA formed in the atmosphere cannot be fully explained by VOC oxidation. The explained percentages of SOA from VOC oxidation were in the range of 34.6-50.9\% under low- $\mathrm{NO}_{\mathrm{x}}$ conditions. The explained percentages were even lower in all of the four scenarios under high- $\mathrm{NO}_{\mathrm{x}}$ conditions. VOC oxidation can explain 10.6$13.9 \%$ of SOA formation, if aromatic yields are calculated from the average OA concentration $\left(15 \mu \mathrm{g} \mathrm{m}^{-3}\right)$ and temperature $\left(10^{\circ} \mathrm{C}\right)$ under high- $\mathrm{NO}_{\mathrm{x}}$ conditions. Applying higher OA concentration $\left(50 \mu \mathrm{g} \mathrm{m}^{-3}\right)$ and lower temperature $\left(0^{\circ} \mathrm{C}\right)$ as inputs of SOA yields elevates the explained percentages of SOA to $16.9-21.5 \%$.

\section{Discussions}

\subsection{Possible reasons for the discrepancies of measured and calculated SOA}

The above results show that VOC oxidation cannot explain SOA formation during the Changdao campaign. As far as we know, our study is the first one to explore the contribution of VOC oxidation to SOA formation based on ambient measurements in China. Our results are consistent with previous studies in other parts of the world (de Gouw et al., 2008; Heald et al., 2005; Matsui et al., 2009; Volkamer et al., 2006). The possible reasons for the large discrepancies between predicted SOA and measured SOA could be the following:

1. In the above calculation, the contributions from biogenic VOCs to SOA are neglected. As shown in Sect. 3.1, the concentration of biogenic species, including isoprene, MVK, MACR and monoterpenes, were low during the Changdao campaign. The average concentrations of isoprene, MVK and MACR were $7 \mathrm{ppt}, 18 \mathrm{ppt}$ and $35 \mathrm{ppt}$, respectively. Using the method shown in Capes et al. (2009), SOA from biogenic VOCs would be less than $0.1 \mu \mathrm{g} \mathrm{m}^{-3}$, which was a minor contributor to the SOA measured from AMS (average $4.2 \mu \mathrm{g} \mathrm{m}^{-3}$ ). A previous WRF-Chem study showed that SOA formation from biogenic VOCs was only $10-20 \%$ of that from anthropogenic VOCs in winter and spring of Shandong Province (Jiang et al., 2012), where the sampling site was located. Even though SOA formation from biogenic VOCs can be enhanced by anthropogenic emissions (Goldstein et al., 2009), biogenic emissions should not be a significant contributor to SOA formation at Changdao.

2. The uptake of glyoxal and methyl glyoxal by aqueous aerosol may be a significant source of SOA in the at-

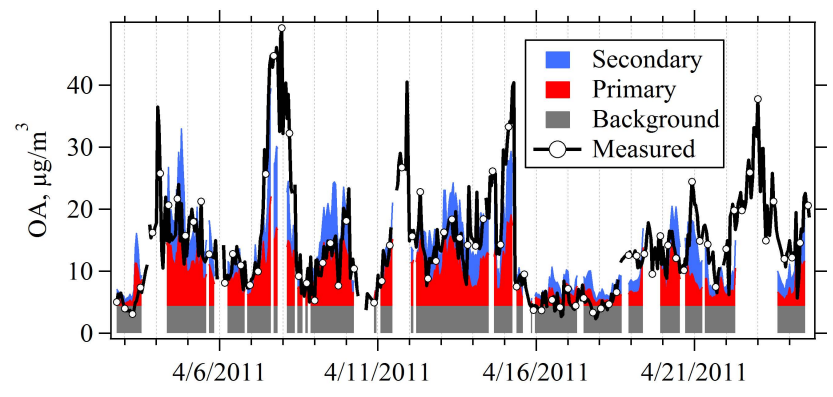

Fig. 6. Time series of measured and calculated concentrations of organic aerosol during the Changdao campaign.

mosphere (Fu et al., 2008). A previous study showed that glyoxal can contribute at least $15 \%$ of SOA formation in Mexico City (Volkamer et al., 2007), but glyoxal only accounted for negligible SOA formation in Los Angeles (0-4\%) (Washenfelder et al., 2011). Fog events associated with high RH (Fig. S3), favoring glyoxal uptake to aerosol, were encountered in the last few days of the campaign (i.e. 21-22 April). Thus, glyoxal could be a significant source of SOA formation during the Changdao campaign. Since glyoxal was not measured at Changdao, the determination of SOA from glyoxal is not possible in this paper.

3. Both laboratory and model evidence showed that semivolatile organic compounds (SVOCs) are important precursors of SOA in the atmosphere (Robinson et al., 2007; Dzepina et al., 2009). Field measurements confirmed that C14-C16 SVOCs are important SOA precursors in the plumes of an oil spill (de Gouw et al., 2011). VOC species measured by online GC-MS/FID and PTR-MS in this study range from 1 to 10 carbon atoms, which is only a subset of organic compounds existing in the atmosphere (Goldstein and Galbally, 2007). Recently, SOA yields of some SVOCs, especially higher alkanes (more than 10 carbon atoms, e.g. > C10) (Lim and Ziemann, 2005; Lim and Ziemann, 2009; Presto et al., 2010) and polycyclic aromatic hydrocarbons (PAHs) (Chan et al., 2009; Shakya and Griffin, 2010) have been simulated in the chamber studies. Measurements of SVOCs, difficult in the ambient atmosphere, have been a major hurdle in the studies of SOA formation from SVOCs. Limited ambient data of gaseous SVOC concentrations are reported in the literature. The contributions of SOA formation from some SVOC species are further explored in Sect. 4.2. 


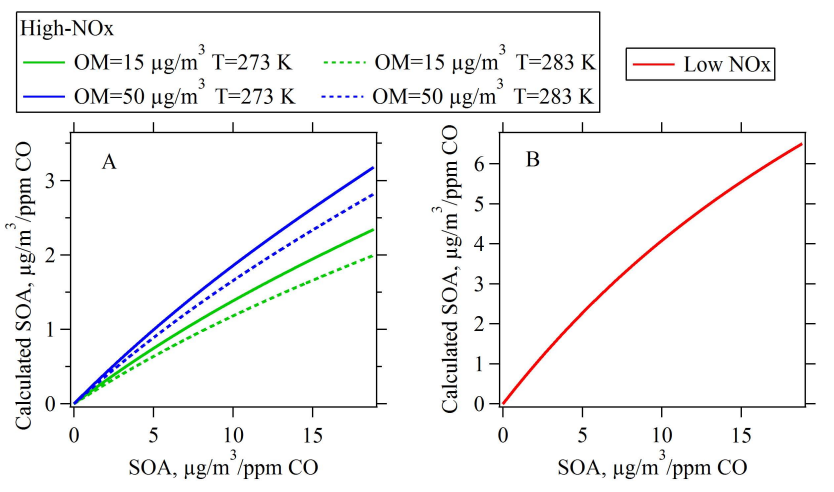

Fig. 7. Correlation of SOA calculated from VOC oxidations and SOA determined from AMS measurements under high-NOx (left) and low-NOx conditions (right).

\subsection{Contributions of SOA from PAHs and higher alkanes (> C10)}

Emission factors of SVOCs from important sources could be used to evaluate the roles of SVOCs in SOA formation (Chan et al., 2009). This method is followed to calculate the contribution of PAHs and higher n-alkanes to SOA formation at Changdao.

Coal burning, biomass burning, coke industry and vehicle emissions are the main sources of PAH emissions in China (Xu et al., 2005). No related information about the sources of higher n-alkanes in China is reported in the literature. Considering the availability of emission factors of gaseous PAHs and higher n-alkanes, emissions from diesel vehicles, coal burning and biomass burning are considered in this study. Emission factors of PAHs and higher n-alkanes for diesel vehicle emissions are from Schauer et al. (1999). Emission factors of PAHs in emissions of coal burning (Table S4) are derived from Shen et al. (2010), and emission factors for biomass burning (Table S5) are from Zhang et al. (2008b) and Shen et al. (2011), which are both conducted in China. The emissions of higher n-alkanes are not reported from coal burning and biomass burning in the literature.

SOA formed from SVOCs after they are emitted from a specific source can be described by (Chan et al., 2009)

$\Delta M_{0, i}=\left[\mathrm{EF}_{i}\right] \times\left(1-\exp \left(-k_{\mathrm{OH}, i}[\mathrm{OH}] \Delta t\right)\right) \times Y_{i}$.

Here, $\left[\mathrm{EF}_{i}\right]$ is the emission factor of species $i$ from the specific source. $\left[\mathrm{EF}_{i}\right]$ has a unit of $\mu \mathrm{g} \mathrm{km}^{-1}$ in diesel vehicle emissions, whereas $\left[\mathrm{EF}_{i}\right]$ has units of $\mathrm{mg} \mathrm{kg}^{-1}$ fuel (e.g. coal or crop straw) in coal burning and biomass burning emissions. Thus, $\Delta M_{0, i}$ is the amount of SOA formed from SVOC species $i$ for $1 \mathrm{~km}$ running of a diesel vehicle or $1 \mathrm{~kg}$ burning of fuels. $[\mathrm{OH}]$ is the average $\mathrm{OH}$ concentration, and the value $\left(0.723 \times 10^{6}\right.$ molecule $\left.\mathrm{cm}^{-3}\right)$ calculated in Sect. 3.2 is used for the calculation. $\Delta t$ is the reaction time. To facilitate the comparison with SOA from measured VOCs, the reaction time is set to $50 \mathrm{~h}$ in this study. $Y_{i}$ is SOA yield of species $i$, and the values are adapted from the previous study (Chan et al., 2009).

The amount of SOA formed from different SVOCs at Changdao could be scaled from the determined SOA from naphthalene (SOA $\mathrm{Sap}_{\text {) }}$ ) at Changdao (Eq. 10) and the calculated $\Delta M_{0}$ for species $i\left(\Delta M_{0, i}\right)$ and $\Delta M_{0}$ for naphthalene $\left(\Delta M_{0, \text { Nap }}\right)$ in Eq. (12). The equation is shown as

$\mathrm{SOA}_{i}=\frac{\Delta M_{0, i}}{\Delta M_{0, \mathrm{Nap}}} \times \mathrm{SOA}_{\mathrm{Nap}}$.

Figure 8 compares the calculated SOA contributions from PAHs and higher n-alkanes with those from measured VOCs under both high- $\mathrm{NO}_{\mathrm{x}}\left(M_{0}=15 \mu \mathrm{g} \mathrm{m}^{-3}\right.$ and $\left.T=10^{\circ} \mathrm{C}\right)$ and low- $\mathrm{NO}_{\mathrm{x}}$ conditions. Note that naphthalene is not included in the category of PAHs in Fig. 8, since naphthalene is regarded as a measured VOC species in this study. SOA formation from PAH oxidations under high$\mathrm{NO}_{\mathrm{x}}$ conditions calculated using emissions of diesel vehicles, coal burning and biomass burning is $1.8 \mu \mathrm{g} \mathrm{m}^{-3} \mathrm{ppm}^{-1}$ $\mathrm{CO}, 1.4 \mu \mathrm{g} \mathrm{m}^{-3} \mathrm{ppm}^{-1} \mathrm{CO}$ and $0.1 \mu \mathrm{g} \mathrm{m}^{-3} \mathrm{ppm}^{-1} \mathrm{CO}$, respectively. SOA from higher $\mathrm{n}$-alkanes oxidation are only calculated from diesel vehicle emissions under high- $\mathrm{NO}_{\mathrm{x}}$ conditions, and it is $1.5 \mu \mathrm{g} \mathrm{m}^{-3} \mathrm{ppm}^{-1} \mathrm{CO}$. Recall that VOC oxidations contribute $2.0 \mu \mathrm{g} \mathrm{m}^{-3} \mathrm{ppm}^{-1} \mathrm{CO}$ to SOA formation under high- $\mathrm{NO}_{\mathrm{x}}$ conditions. PAHs and higher n-alkanes totally account for up to $17.4 \%$ of the measured SOA formation $\left(18.8 \mu \mathrm{g} \mathrm{m}^{-3} \mathrm{ppm}^{-1} \mathrm{CO}\right)$ at Changdao. The contribution of PAHs to SOA formation is even higher using low- $\mathrm{NO}_{\mathrm{x}}$ yields. SOA formation from PAHs calculated using emissions of diesel vehicle under low- $\mathrm{NO}_{\mathrm{x}}$ conditions is $3.0 \mu \mathrm{g} \mathrm{m}^{-3} \mathrm{ppm}^{-1} \mathrm{CO}$ (16.1\% of the measured SOA).

The results show that PAHs and higher alkanes contributed significantly to SOA formation at Changdao. However, our study only evaluates two types of SVOCs (PAHs and higher n-alkanes). Other SVOC species, such as longchain branched alkanes, C9-C20 substituted cyclohexanes, C10-C14 aldehydes and C7-C18 alkanoic acids, were also abundant in emissions of sources and ambient air (Schauer et al., 1999; Williams et al., 2010). These compounds could also be important SOA precursors in the atmosphere. This suggests that SVOC contributions to SOA formation may be even larger.

\subsection{Implications of SOA formation in China}

VOC emission ratios to $\mathrm{CO}$ determined in Changdao are compared with the results from an urban site in Beijing and also the values in emission inventories (see Sect. 3.4). Here, the SOA formation potential of VOC emissions, which is the emission ratios of VOCs to CO times SOA yields, is introduced. The SOA formation potential represents the maximum SOA formation from VOC oxidations under the condition that primary emissions maintain $\mathrm{CO}$ concentrations at $1 \mathrm{ppm}$ in the atmosphere. The SOA formation potential has a unit of $\mu \mathrm{g} \mathrm{m}^{-3} \mathrm{ppm}^{-1}$. 

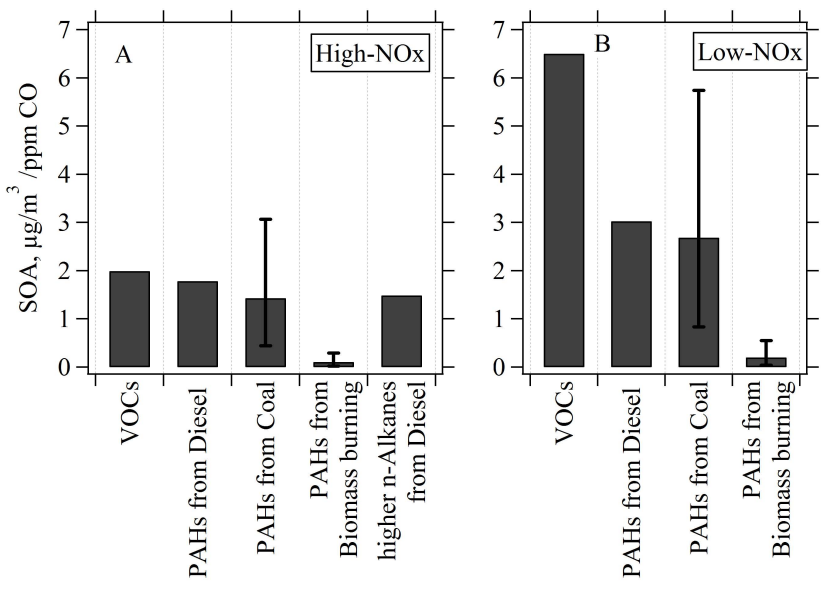

Fig. 8. Comparisons of SOA formation from VOC oxidation, and from PAHs and higher n-alkanes using emission factors of various sources after $50 \mathrm{~h}$ oxidations under both high- $\mathrm{NO}_{\mathrm{x}}(\mathrm{A})$ and lowNOx (B) conditions. Error bars in the PAH contributions of coal burning and biomass burning represent the highest and lowest calculated values from different types of coals or crop straws.

The SOA formation potential in Changdao and Beijing campaigns is $9 \mu \mathrm{g} \mathrm{m}^{-3} \mathrm{ppm}^{-1}$ and $26 \mu \mathrm{g} \mathrm{m}^{-3} \mathrm{ppm}^{-1}$, respectively (Fig. 9a). The differences between the two campaigns are mainly due to the discrepancies in emission ratios of aromatics. Calculations based on six selected aromatic species (values are shown in Table S6) indicate that the SOA formation potential of VOC emissions in PRD is close to the value in Beijing $\left(25.7 \mu \mathrm{g} \mathrm{m}^{-3} \mathrm{ppm}^{-1}\right)$ (Fig. 9b).

Figure 9a also shows the SOA formation potential of VOC emissions in the emission inventory of each province of China. SOA formation potentials of VOC emissions in emission inventories of different provinces are in the range of $7-$ $30 \mu \mathrm{g} \mathrm{m}^{-3} \mathrm{ppm}^{-1}$. The highest SOA formation potential is obtained in Hong Kong. Aromatics are the dominant contributors to SOA formation potential in the data from both emission inventories and field campaigns. It is interesting to note that SOA formation potentials show clearly positive correlation with gross domestic product (GDP) per capita in each province (Fig. 9c), indicating SOA formation is increasing alongside the development of the economy in China.

Ambient OA/CO ratio data in China is limited in the literature. The OA/CO ratio increased by $18.8 \mu \mathrm{g} \mathrm{m}^{-3} \mathrm{ppm}^{-1}$ after $50 \mathrm{~h}$ of photochemical processing based on the results of the Changdao campaign. SOA formation in Changdao is somewhat lower than the results in other regions (de Gouw and Jimenez, 2009), maybe due to the lower intensity of photochemical oxidation in April. A study in southern China showed that the OA/CO ratio increased from $15.3 \mu \mathrm{g} \mathrm{m}^{-3} \mathrm{ppm}^{-1}$ at 7:00 to $110.9 \mu \mathrm{g} \mathrm{m}^{-3} \mathrm{ppm}^{-1}$ at $15: 00$ at a rural site (Backgarden, BG) in PRD, translating to SOA formation of $95.6 \mu \mathrm{g} \mathrm{m}^{-3} \mathrm{ppm}^{-1} \mathrm{CO}$ (Hu et al., 2012). Measurements from AMS data at an urban site in summer of Bei- jing showed that the average SOA/CO ratio at 14:00 was $35.2 \mathrm{\mu g} \mathrm{m}^{-3} \mathrm{ppm}^{-1}$ and about $10 \%$ of SOA / CO ratios were larger than $40 \mu \mathrm{g} \mathrm{m}^{-3} \mathrm{ppm}^{-1}$ (W. W. Hu, personal communication, 2012). The results showed that SOA formation at the BG site and at the urban site in Beijing were also significantly higher than SOA formation potentials of VOCs emissions determined from both VOC ambient measurements $\left(9-25 \mu \mathrm{g} \mathrm{m}^{-3} \mathrm{ppm}^{-1}\right)$ and emission inventory data (7$30 \mu \mathrm{g} \mathrm{m}^{-3} \mathrm{ppm}^{-1}$ ). It indicates that VOC oxidations cannot explain SOA formation either in Beijing or PRD, two important city clusters in China.

\section{Conclusions}

VOCs were measured by a GC-MS/FID and a PTR-MS at a receptor site in Bohai Sea in eastern China. VOC concentrations clearly showed dependence on wind directions, with high concentrations from the south/southwest and low concentration from the north/northeast. The dependence was consistent with the location of the Changdao site and the source strengths in the surrounding regions.

Chemical losses of various VOC species in the atmosphere were dominated by reactions with $\mathrm{OH}$ radical during the Changdao campaign. A parameterization method based on photochemical age is used to characterize the evolutions of hydrocarbons and OVOCs. Comparisons of emission ratios of VOCs with those in other regions and in emission inventory data showed that hydrocarbon emissions are well estimated in emission inventory data, but OVOC emissions are significantly underestimated in emission inventory data. The underestimate of OVOC emissions is possibly due to the poor knowledge on emission patterns of non-vehicle sources to OVOCs.

The parameterization method is also used to resolve the evolution of $\mathrm{OA}$ in the atmosphere. SOA formation relative to $\mathrm{CO}$ is $18.8 \mu \mathrm{g} \mathrm{m}^{-3} \mathrm{ppm}^{-1}$ after $50 \mathrm{~h}$ oxidation. SOA formation is also determined from VOC evolution equations at high- $\mathrm{NO}_{\mathrm{x}}$ and low- $\mathrm{NO}_{\mathrm{x}}$ conditions. VOC oxidation can only explain 34.6-50.9\% of SOA formation under low- $\mathrm{NO}_{\mathrm{x}}$ conditions, whereas less than $13.6 \%$ of SOA formation is explainable using high- $\mathrm{NO}_{x}$ parameters. These numbers indicate that SOA formation is significantly larger than expected during the Changdao campaign. Using the data in emission inventory and literature values, it is shown that SOA formation in Beijing and PRD is also notably larger than the SOA formation potential of VOC emissions. SVOCs could account for a large fraction of the unexplained SOA formation during the Changdao campaign. PAHs and higher alkanes (> C10) contributed to as much as $17.4 \%$ of SOA formation during the Changdao campaign. Our findings emphasize the importance of SVOC measurements in the atmosphere. 

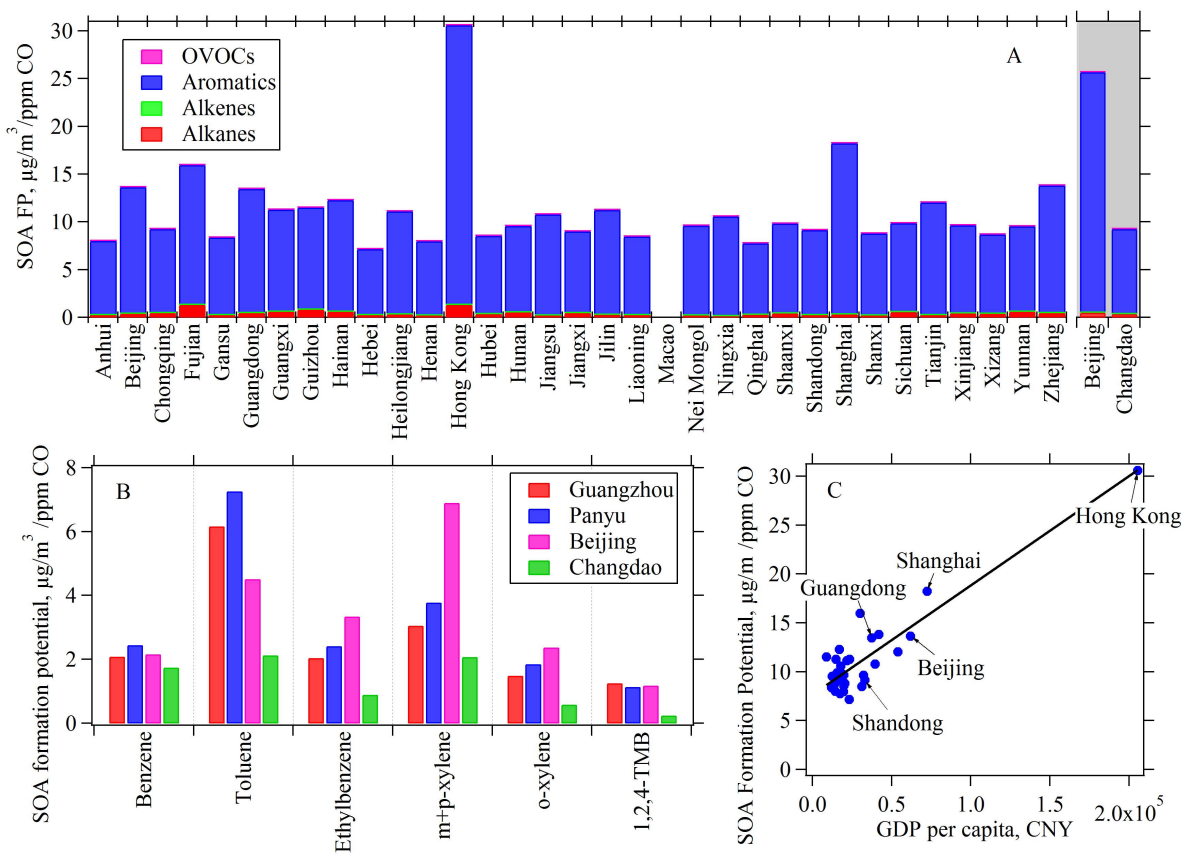

Fig. 9. (A) SOA formation potentials of VOC emissions calculated from initial emission ratios of VOCs to CO in the emission inventory of each province and from the results of field measurements (shaded areas) at an urban site in Beijing (Yuan et al., 2012) and during the Changdao campaign. (B) Comparison of SOA formation potentials of six aromatics at two sites in PRD (Guangzhou and Panyu) with those in Beijing and Changdao. (C) Scatterplots of SOA formation potential of VOC emissions in each province with gross domestic product (GDP) per capita in each province.

\section{Supplementary material related to this article is available online at http://www.atmos-chem-phys.net/13/ 8815/2013/acp-13-8815-2013-supplement.pdf.}

Acknowledgements. This work was supported by the China Ministry of Environmental Protection's Special Funds for Scientific Research on Public Welfare (201009002) and Natural Science Foundation for Outstanding Young Scholars (Grant No. 41125018).

Edited by: K. Schaefer

\section{References}

Apel, E. C., Emmons, L. K., Karl, T., Flocke, F., Hills, A. J., Madronich, S., Lee-Taylor, J., Fried, A., Weibring, P., Walega, J., Richter, D., Tie, X., Mauldin, L., Campos, T., Weinheimer, A., Knapp, D., Sive, B., Kleinman, L., Springston, S., Zaveri, R., Ortega, J., Voss, P., Blake, D., Baker, A., Warneke, C., Welsh-Bon, D., de Gouw, J., Zheng, J., Zhang, R., Rudolph, J., Junkermann, W., and Riemer, D. D.: Chemical evolution of volatile organic compounds in the outflow of the Mexico City Metropolitan area, Atmos. Chem. Phys., 10, 2353-2375, doi:10.5194/acp-10-23532010, 2010.

Atkinson, R. and Arey, J.: Atmospheric degradation of volatile organic compounds, Chem. Rev., 103, 4605-4638, doi:10.1021/Cr0206420, 2003.
Bahreini, R., Ervens, B., Middlebrook, A. M., Warneke, C., de Gouw, J. A., DeCarlo, P. F., Jimenez, J. L., Brock, C. A., Neuman, J. A., Ryerson, T. B., Stark, H., Atlas, E., Brioude, J., Fried, A., Holloway, J. S., Peischl, J., Richter, D., Walega, J., Weibring, P., Wollny, A. G., and Fehsenfeld, F. C.: Organic aerosol formation in urban and industrial plumes near Houston and Dallas, Texas, J. Geophys. Res.-Atmos., 114, D00F16, doi:10.1029/2008JD011493, 2009.

Ban-Weiss, G. A., Mclaughlin, J. P., Harley, R. A., Kean, A. J., Grosjean, E., and Grosjean, D.: Carbonyl and nitrogen dioxide emissions from gasoline- and diesel-powered motor vehicles, Environ. Sci. Technol., 42, 3944-3950, doi:10.1021/Es8002487, 2008.

Bon, D. M., Ulbrich, I. M., de Gouw, J. A., Warneke, C., Kuster, W. C., Alexander, M. L., Baker, A., Beyersdorf, A. J., Blake, D., Fall, R., Jimenez, J. L., Herndon, S. C., Huey, L. G., Knighton, W. B., Ortega, J., Springston, S., and Vargas, O.: Measurements of volatile organic compounds at a suburban ground site (T1) in Mexico City during the MILAGRO 2006 campaign: measurement comparison, emission ratios, and source attribution, Atmos. Chem. Phys., 11, 2399-2421, doi:10.5194/acp-11-23992011, 2011.

Capes, G., Murphy, J. G., Reeves, C. E., McQuaid, J. B., Hamilton, J. F., Hopkins, J. R., Crosier, J., Williams, P. I., and Coe, H.: Secondary organic aerosol from biogenic VOCs over West Africa during AMMA, Atmos. Chem. Phys., 9, 3841-3850, doi:10.5194/acp-9-3841-2009, 2009.

Chan, A. W. H., Kautzman, K. E., Chhabra, P. S., Surratt, J. D. Chan, M. N., Crounse, J. D., Kürten, A., Wennberg, P. O., 
Flagan, R. C., and Seinfeld, J. H.: Secondary organic aerosol formation from photooxidation of naphthalene and alkylnaphthalenes: implications for oxidation of intermediate volatility organic compounds (IVOCs), Atmos. Chem. Phys., 9, 3049-3060, doi:10.5194/acp-9-3049-2009, 2009.

de Gouw, J. and Jimenez, J. L.: Organic Aerosols in the Earth's Atmosphere, Environ. Sci. Technol., 43, 7614-7618, doi:10.1021/es9006004, 2009.

de Gouw, J. A., Middlebrook, A. M., Warneke, C., Goldan, P. D., Kuster, W. C., Roberts, J. M., Fehsenfeld, F. C., Worsnop, D. R., Canagaratna, M. R., Pszenny, A. A. P., Keene, W. C., Marchewka, M., Bertman, S. B., and Bates, T. S.: Budget of organic carbon in a polluted atmosphere: Results from the New England Air Quality Study in 2002, J. Geophys. Res.-Atmos., 110, D16305, doi:10.1029/2004jd005623, 2005.

de Gouw, J. A., Brock, C. A., Atlas, E. L., Bates, T. S., Fehsenfeld, F. C., Goldan, P. D., Holloway, J. S., Kuster, W. C., Lerner, B. M., Matthew, B. M., Middlebrook, A. M., Onasch, T. B., Peltier, R. E., Quinn, P. K., Senff, C. J., Stohl, A., Sullivan, A. P., Trainer, M., Warneke, C., Weber, R. J., and Williams, E. J.: Sources of particulate matter in the northeastern United States in summer: 1. Direct emissions and secondary formation of organic matter in urban plumes, J. Geophys. Res.-Atmos., 113, D08301, doi:08310.01029/02007JD009243, 2008.

de Gouw, J. A., Middlebrook, A. M., Warneke, C., Ahmadov, R., Atlas, E. L., Bahreini, R., Blake, D. R., Brock, C. A., Brioude, J., Fahey, D. W., Fehsenfeld, F. C., Holloway, J. S., Le Henaff, M., Lueb, R. A., McKeen, S. A., Meagher, J. F., Murphy, D. M., Paris, C., Parrish, D. D., Perring, A. E., Pollack, I. B., Ravishankara, A. R., Robinson, A. L., Ryerson, T. B., Schwarz, J. P., Spackman, J. R., Srinivasan, A., and Watts, L. A.: Organic Aerosol Formation Downwind from the Deepwater Horizon Oil Spill, Science, 331, 1295-1299, doi:10.1126/science.1200320, 2011.

De Smedt, I., Stavrakou, T., Muller, J. F., van der A, R. J., and Van Roozendael, M.: Trend detection in satellite observations of formaldehyde tropospheric columns, Geophys. Res. Lett., 37 , L18808, doi:10.1029/2010g1044245, 2010.

Draxler, R. R. and Rolph, G. D.: HYSPLIT (HYbrid Single-Particle Lagrangian Integrated Trajectory) Model access via NOAA ARL READY Website (http://www.arl.noaa.gov/HYSPLIT. php), NOAA Air Resources Laboratory, Silver Spring, MD, 2003.

Dzepina, K., Volkamer, R. M., Madronich, S., Tulet, P., Ulbrich, I. M., Zhang, Q., Cappa, C. D., Ziemann, P. J., and Jimenez, J. L.: Evaluation of recently-proposed secondary organic aerosol models for a case study in Mexico City, Atmos. Chem. Phys., 9, 5681-5709, doi:10.5194/acp-9-5681-2009, 2009.

Ehhalt, D. H. and Rohrer, F.: Dependence of the $\mathrm{OH}$ concentration on solar UV, J. Geophys. Res.-Atmos., 105, 3565-3571, 2000.

Fu, T. M., Jacob, D. J., Wittrock, F., Burrows, J. P., Vrekoussis, M., and Henze, D. K.: Global budgets of atmospheric glyoxal and methylglyoxal, and implications for formation of secondary organic aerosols, J. Geophys. Res.-Atmos., 113, D15303, doi:10.1029/2007jd009505, 2008.

Fu, T.-M., Cao, J. J., Zhang, X. Y., Lee, S. C., Zhang, Q., Han, Y. M., Qu, W. J., Han, Z., Zhang, R., Wang, Y. X., Chen, D., and Henze, D. K.: Carbonaceous aerosols in China: top-down constraints on primary sources and estimation of secondary contri- bution, Atmos. Chem. Phys., 12, 2725-2746, doi:10.5194/acp12-2725-2012, 2012.

Goldstein, A. H. and Galbally, I. E.: Known and Unexplored Organic Constituents in the Earth's Atmosphere, Environ. Sci. Technol., 41, 1514-1521, doi:10.1021/es072476p, 2007.

Goldstein, A. H., Koven, C. D., Heald, C. L., and Fung, I. Y.: Biogenic carbon and anthropogenic pollutants combine to form a cooling haze over the southeastern United States, P. Natl. Acad. Sci., 106, 8835-8840, doi:10.1073/pnas.0904128106, 2009.

Han, Z., Zhang, R., Wang, Q. g., Wang, W., Cao, J., and Xu, J.: Regional modeling of organic aerosols over China in summertime, J. Geophys. Res., 113, D11202, doi:10.1029/2007jd009436, 2008.

Heald, C. L., Jacob, D. J., Park, R. J., Russell, L. M., Huebert, B. J., Seinfeld, J. H., Liao, H., and Weber, R. J.: A large organic aerosol source in the free troposphere missing from current models, Geophys. Res. Lett., 32, L18809, doi:10.1029/2005gl023831, 2005.

Henze, D. K., Seinfeld, J. H., Ng, N. L., Kroll, J. H., Fu, T.-M., Jacob, D. J., and Heald, C. L.: Global modeling of secondary organic aerosol formation from aromatic hydrocarbons: highvs. low-yield pathways, Atmos. Chem. Phys., 8, 2405-2420, doi:10.5194/acp-8-2405-2008, 2008.

Hu, W. W., Hu, M., Deng, Z. Q., Xiao, R., Kondo, Y., Takegawa, N., Zhao, Y. J., Guo, S., and Zhang, Y. H.: The characteristics and origins of carbonaceous aerosol at a rural site of PRD in summer of 2006, Atmos. Chem. Phys., 12, 1811-1822, doi:10.5194/acp12-1811-2012, 2012.

Hu, W. W., Hu, M., Yuan, B., Jimenez, J. L., Tang, Q., Peng, J. F., Hu, W., Shao, M., Wang, M., Zeng, L. M., Wu, Y. S., Gong, Z. H., Huang, X. F., and He, L. Y.: Insights on organic aerosol aging and the influence of coal combustion at a regional receptor site of Central Eastern China, Atmos. Chem. Phys. Discuss., 13, 10809-10858, doi:10.5194/acpd-13-10809-2013, 2013.

Huang, X.-F., He, L.-Y., Hu, M., Canagaratna, M. R., Sun, Y., Zhang, Q., Zhu, T., Xue, L., Zeng, L.-W., Liu, X.-G., Zhang, Y.-H., Jayne, J. T., Ng, N. L., and Worsnop, D. R.: Highly time-resolved chemical characterization of atmospheric submicron particles during 2008 Beijing Olympic Games using an Aerodyne High-Resolution Aerosol Mass Spectrometer, Atmos. Chem. Phys., 10, 8933-8945, doi:10.5194/acp-10-8933-2010, 2010.

Huang, X.-F., He, L.-Y., Hu, M., Canagaratna, M. R., Kroll, J. H., Ng, N. L., Zhang, Y.-H., Lin, Y., Xue, L., Sun, T.-L., Liu, X.-G., Shao, M., Jayne, J. T., and Worsnop, D. R.: Characterization of submicron aerosols at a rural site in Pearl River Delta of China using an Aerodyne High-Resolution Aerosol Mass Spectrometer, Atmos. Chem. Phys., 11, 1865-1877, doi:10.5194/acp-11-18652011, 2011.

Jiang, F., Liu, Q., Huang, X., Wang, T., Zhuang, B., and Xie, M.: Regional modeling of secondary organic aerosol over China using WRF/Chem, J. Aerosol. Sci., 43, 57-73, doi:10.1016/j.jaerosci.2011.09.003, 2012.

Koch, D.: Transport and direct radiative forcing of carbonaceous and sulfate aerosols in the GISS GCM, J. Geophys. Res., 106, 20311-20332, doi:10.1029/2001jd900038, 2001.

Kondo, Y., Oshima, N., Kajino, M., Mikami, R., Moteki, N., Takegawa, N., Verma, R. L., Kajii, Y., Kato, S., and Takami, A.: Emissions of black carbon in East Asia estimated from observations at a remote site in the East China Sea, J. Geophys. Res., 
116, D16201, doi:10.1029/2011jd015637, 2011.

Kristensson, A., Johansson, C., Westerholm, R., Swietlicki, E., Gidhagen, L., Wideqvist, U., and Vesely, V.: Real-world traffic emission factors of gases and particles measured in a road tunnel in Stockholm, Sweden, Atmos. Environ., 38, 657-673, doi:10.1016/j.atmosenv.2003.10.030, 2004.

Langford, B., Davison, B., Nemitz, E., and Hewitt, C. N.: Mixing ratios and eddy covariance flux measurements of volatile organic compounds from an urban canopy (Manchester, UK), Atmos. Chem. Phys., 9, 1971-1987, doi:10.5194/acp-9-1971-2009, 2009.

Langford, B., Nemitz, E., House, E., Phillips, G. J., Famulari, D., Davison, B., Hopkins, J. R., Lewis, A. C., and Hewitt, C. N.: Fluxes and concentrations of volatile organic compounds above central London, UK, Atmos. Chem. Phys., 10, 627-645, doi:10.5194/acp-10-627-2010, 2010.

Lim, Y. B. and Ziemann, P. J.: Products and Mechanism of Secondary Organic Aerosol Formation from Reactions of n-Alkanes with $\mathrm{OH}$ Radicals in the Presence of $\mathrm{NO}_{\mathrm{x}}$, Environ. Sci. Technol., 39, 9229-9236, doi:10.1021/es051447g, 2005.

Lim, Y. B. and Ziemann, P. J.: Effects of Molecular Structure on Aerosol Yields from OH Radical-Initiated Reactions of Linear, Branched, and Cyclic Alkanes in the Presence of $\mathrm{NO}_{\mathrm{x}}$, Environ. Sci. Technol., 43, 2328-2334, doi:10.1021/es803389s, 2009.

Liu, Y., Shao, M., Fu, L. L., Lu, S. H., Zeng, L. M., and Tang, D. G.: Source profiles of volatile organic compounds (VOCs) measured in China: Part I, Atmos. Environ., 42, 6247-6260, doi:10.1016/j.atmosenv.2008.01.070, 2008.

Matsui, H., Koike, M., Takegawa, N., Kondo, Y., Griffin, R. J., Miyazaki, Y., Yokouchi, Y., and Ohara, T.: Secondary organic aerosol formation in urban air: Temporal variations and possible contributions from unidentified hydrocarbons, J. Geophys. Res.Atmos., 114, D04201, doi:10.1029/2008jd010164, 2009.

Millet, D. B., Goldstein, A. H., Allan, J. D., Bates, T. S., Boudries, H., Bower, K. N., Coe, H., Ma, Y. L., McKay, M., Quinn, P. K., Sullivan, A., Weber, R. J., and Worsnop, D. R.: Volatile organic compound measurements at Trinidad Head, California, during ITCT 2K2: Analysis of sources, atmospheric composition, and aerosol residence times, J. Geophys. Res.-Atmos., 109, D23S16, doi:10.1029/2003JD004026, 2004.

Ng, N. L., Kroll, J. H., Chan, A. W. H., Chhabra, P. S., Flagan, R. C., and Seinfeld, J. H.: Secondary organic aerosol formation from m-xylene, toluene, and benzene, Atmos. Chem. Phys., 7, 3909-3922, doi:10.5194/acp-7-3909-2007, 2007.

Niedojadlo, A., Becker, K. H., Kurtenbach, R., and Wiesen, P.: The contribution of traffic and solvent use to the total NMVOC emission in a German city derived from measurements and CMB modelling, Atmos. Environ., 41, 7108-7126, doi:10.1016/j.atmosenv.2007.04.056, 2007.

Odum, J. R., Hoffmann, T., Bowman, F., Collins, D., Flagan, R. C., and Seinfeld, J. H.: Gas/Particle Partitioning and Secondary Organic Aerosol Yields, Environ. Sci. Technol., 30, 2580-2585, doi:10.1021/es950943+, 1996.

Parrish, D. D., Stohl, A., Forster, C., Atlas, E. L., Blake, D. R., Goldan, P. D., Kuster, W. C., and de Gouw, J. A.: Effects of mixing on evolution of hydrocarbon ratios in the troposphere, J. Geophys. Res.-Atmos., 112, D10S34, doi:10.1029/2006JD007583, 2007.
Parrish, D. D., Kuster, W. C., Shao, M., Yokouchi, Y., Kondo, Y., Goldan, P. D., de Gouw, J. A., Koike, M., and Shirai, T.: Comparison of air pollutant emissions among mega-cities, Atmos. Environ., 43, 6435-6441, 2009.

Presto, A. A., Miracolo, M. A., Donahue, N. M., and Robinson, A. L.: Secondary Organic Aerosol Formation from High- $\mathrm{NO}_{\mathrm{x}}$ Photo-Oxidation of Low Volatility Precursors: n-Alkanes, Environ. Sci. Technol., 44, 2029-2034, doi:10.1021/es903712r, 2010.

Robinson, A. L., Donahue, N. M., Shrivastava, M. K., Weitkamp, E. A., Sage, A. M., Grieshop, A. P., Lane, T. E., Pierce, J. R., and Pandis, S. N.: Rethinking organic aerosols: Semivolatile emissions and photochemical aging, Science, 315, 1259-1262, doi:10.1126/science.1133061, 2007.

Schauer, J. J., Kleeman, M. J., Cass, G. R., and Simoneit, B. R. T.: Measurement of Emissions from Air Pollution Sources. 2. C1 through C30 Organic Compounds from Medium Duty Diesel Trucks, Environ. Sci. Technol., 33, 1578-1587, doi:10.1021/es980081n, 1999.

Shakya, K. M. and Griffin, R. J.: Secondary Organic Aerosol from Photooxidation of Polycyclic Aromatic Hydrocarbons, Environ. Sci. Technol., 44, 8134-8139, doi:10.1021/es1019417, 2010.

Shao, M., Wang, B., Lu, S., Yuan, B., and Wang, M.: Effects of Beijing Olympics Control Measures on Reducing Reactive Hydrocarbon Species, Environ. Sci. Technol., 45, 514-519, doi:10.1021/es102357t, 2011.

Shen, G., Wang, W., Yang, Y., Zhu, C., Min, Y., Xue, M., Ding, J., Li, W., Wang, B., Shen, H., Wang, R., Wang, X., and Tao, S.: Emission factors and particulate matter size distribution of polycyclic aromatic hydrocarbons from residential coal combustions in rural Northern China, Atmos. Environ., 44, 5237-5243, doi:10.1016/j.atmosenv.2010.08.042, 2010.

Shen, G., Wang, W., Yang, Y., Ding, J., Xue, M., Min, Y., Zhu, C., Shen, H., Li, W., Wang, B., Wang, R., Wang, X., Tao, S., and Russell, A. G.: Emissions of PAHs from Indoor Crop Residue Burning in a Typical Rural Stove: Emission Factors, Size Distributions, and Gas-Particle Partitioning, Environ. Sci. Technol., 45, 1206-1212, doi:10.1021/es102151w, 2011.

Shirai, T., Yokouchi, Y., Blake, D. R., Kita, K., Izumi, K., Koike, M., Komazaki, Y., Miyazaki, Y., Fukuda, M., and Kondo, Y.: Seasonal variations of atmospheric C2-C7 nonmethane hydrocarbons in Tokyo, J. Geophys. Res.-Atmos., 112, D24305, doi:10.1029/2006jd008163, 2007.

Suthawaree, J., Kato, S., Okuzawa, K., Kanaya, Y., Pochanart, P., Akimoto, H., Wang, Z., and Kajii, Y.: Measurements of volatile organic compounds in the middle of Central East China during Mount Tai Experiment 2006 (MTX2006): observation of regional background and impact of biomass burning, Atmos. Chem. Phys., 10, 1269-1285, doi:10.5194/acp-10-1269-2010, 2010.

Suthawaree, J., Kato, S., Pochanart, P., Kanaya, Y., Akimoto, H., Wang, Z., and Kajii, Y.: Influence of Beijing outflow on Volatile Organic Compounds (VOC) observed at a mountain site in North China Plain, Atmos. Res., 111, 46-57, 2012.

Takegawa, N., Miyakawa, T., Kondo, Y., Blake, D. R., Kanaya, Y., Koike, M., Fukuda, M., Komazaki, Y., Miyazaki, Y., Shimono, A., and Takeuchi, T.: Evolution of submicron organic aerosol in polluted air exported from Tokyo, Geophys. Res. Lett., 33, L15814, doi:10.1029/2006g1025815, 2006. 
van der A, R. J., Eskes, H. J., Boersma, K. F., van Noije, T. P. C., Van Roozendael, M., De Smedt, I., Peters, D. H. M. U., and Meijer, E. W.: Trends, seasonal variability and dominant $\mathrm{NO}_{\mathrm{x}}$ source derived from a ten year record of $\mathrm{NO} 2$ measured from space, $\mathrm{J}$. Geophys. Res., 113, D04302, doi:10.1029/2007jd009021, 2008.

van Donkelaar, A., Martin, R. V., Brauer, M., Kahn, R., Levy, R., Verduzco, C., and Villeneuve, P. J.: Global estimates of ambient fine particulate matter concentrations from satellite-based aerosol optical depth: development and application, Environ. Health Perspect., 118, 847-855, 2010.

Velasco, E., Lamb, B., Pressley, S., Allwine, E., Westberg, H., Jobson, B. T., Alexander, M., Prazeller, P., Molina, L., and Molina, M.: Flux measurements of volatile organic compounds from an urban landscape, Geophys. Res. Lett., 32, L20802, doi:10.1029/2005g1023356, 2005.

Volkamer, R., Jimenez, J. L., San Martini, F., Dzepina, K., Zhang, Q., Salcedo, D., Molina, L. T., Worsnop, D. R., and Molina, M. J.: Secondary organic aerosol formation from anthropogenic air pollution: Rapid and higher than expected, Geophys. Res. Lett., 33, L17811, doi:10.1029/2006g1026899, 2006.

Volkamer, R., Martini, F. S., Molina, L. T., Salcedo, D., Jimenez, J. L., and Molina, M. J.: A missing sink for gas-phase glyoxal in Mexico City: Formation of secondary organic aerosol, Geophys. Res. Lett., 34, L19807, doi:10.1029/2007g1030752, 2007.

Volkamer, R., Ziemann, P. J., and Molina, M. J.: Secondary Organic Aerosol Formation from Acetylene $\left(\mathrm{C}_{2} \mathrm{H}_{2}\right)$ : seed effect on SOA yields due to organic photochemistry in the aerosol aqueous phase, Atmos. Chem. Phys., 9, 1907-1928, doi:10.5194/acp9-1907-2009, 2009.

Warneke, C., de Gouw, J. A., Goldan, P. D., Kuster, W. C., Williams, E. J., Lerner, B. M., Jakoubek, R., Brown, S. S., Stark, H., Aldener, M., Ravishankara, A. R., Roberts, J. M., Marchewka, M., Bertman, S., Sueper, D. T., McKeen, S. A., Meagher, J. F., and Fehsenfeld, F. C.: Comparison of daytime and nighttime oxidation of biogenic and anthropogenic VOCs along the New England coast in summer during New England Air Quality Study 2002, J. Geophys. Res.-Atmos., 109, D10309, doi:10.1029/2003jd004424, 2004.

Warneke, C., McKeen, S. A., de Gouw, J. A., Goldan, P. D., Kuster, W. C., Holloway, J. S., Williams, E. J., Lerner, B. M., Parrish, D. D., Trainer, M., Fehsenfeld, F. C., Kato, S., Atlas, E. L., Baker, A., and Blake, D. R.: Determination of urban volatile organic compound emission ratios and comparison with an emissions database, J. Geophys. Res.-Atmos., 112, D10S47, doi:10.1029/2006JD007930, 2007.
Washenfelder, R. A., Young, C. J., Brown, S. S., Angevine, W. M., Atlas, E. L., Blake, D. R., Bon, D. M., Cubison, M. J., de Gouw, J. A., Dusanter, S., Flynn, J., Gilman, J. B., Graus, M., Griffith, S., Grossberg, N., Hayes, P. L., Jimenez, J. L., Kuster, W. C., Lefer, B. L., Pollack, I. B., Ryerson, T. B., Stark, H., Stevens, P. S., and Trainer, M. K.: The glyoxal budget and its contribution to organic aerosol for Los Angeles, California, during CalNex 2010, J. Geophys. Res., 116, D00V02, doi:10.1029/2011jd016314, 2011.

Williams, B. J., Goldstein, A. H., Kreisberg, N. M., and Hering, S. V.: In situ measurements of gas/particle-phase transitions for atmospheric semivolatile organic compounds, P. Natl. Acad. Sci., 107, 6676-6681, doi:10.1073/pnas.0911858107, 2010.

$\mathrm{Xu}$, S., Liu, W., and Tao, S.: Emission of Polycyclic Aromatic Hydrocarbons in China, Environ. Sci. Technol., 40, 702-708, doi:10.1021/es0517062, 2005.

Yuan, B., Shao, M., de Gouw, J., Parrish, D., Lu, S. H., Wang, M., Zeng, L. M., Zhang, Q., Song, Y., Zhang, J. B., and Hu, M.: Volatile Organic Compounds (VOCs) in Urban Air: How Chemistry Affects the Interpretation of Positive Matrix Factorization (PMF) Analysis, J. Geophys. Res., 117, D24302, doi:10.1029/2012jd018236, 2012.

Zhang, Q., Streets, D. G., Carmichael, G. R., He, K. B., Huo, H., Kannari, A., Klimont, Z., Park, I. S., Reddy, S., Fu, J. S., Chen, D., Duan, L., Lei, Y., Wang, L. T., and Yao, Z. L.: Asian emissions in 2006 for the NASA INTEX-B mission, Atmos. Chem. Phys., 9, 5131-5153, doi:10.5194/acp-9-5131-2009, 2009.

Zhang, X. Y., Wang, Y. Q., Zhang, X. C., Guo, W., and Gong, S. L.: Carbonaceous aerosol composition over various regions of China during 2006, J. Geophys. Res., 113, D14111, doi:10.1029/2007jd009525, 2008a.

Zhang, Y., Dou, H., Chang, B., Wei, Z., Qiu, W., Liu, S., Liu, W., and Tao, S.: Emission of Polycyclic Aromatic Hydrocarbons from Indoor Straw Burning and Emission Inventory Updating in China, Annals of the New York Academy of Sciences, 1140, 218-227, doi:10.1196/annals.1454.006, 2008b.

Zheng, J., Hu, M., Zhang, R., Yue, D., Wang, Z., Guo, S., Li, X., Bohn, B., Shao, M., He, L., Huang, X., Wiedensohler, A. and Zhu, T.: Measurements of gaseous $\mathrm{H}_{2} \mathrm{SO}_{4}$ by AP-ID-CIMS during CAREBeijing 2008 Campaign, Atmos. Chem. Phys., 11, 7755-7765, doi:10.5194/acp-11-7755-2011, 2011.

Zheng, M., Salmon, L. G., Schauer, J. J., Zeng, L., Kiang, C. S., Zhang, Y., and Cass, G. R.: Seasonal trends in $\mathrm{PM}_{2.5}$ source contributions in Beijing, China, Atmos. Environ., 39, 3967-3976, doi:10.1016/j.atmosenv.2005.03.036, 2005. 